\title{
Clinical Practice Guidelines for Functional Dyspepsia in Korea
}

\author{
Jung Hwan Oh, ${ }^{1}$ Joong Goo Kwon, ${ }^{2 *}$ Hye-Kyung Jung, ${ }^{3 *}$ Chung Hyun Tae, ${ }^{3}$ Kyung Ho Song, ${ }^{4}$ Seung Joo Kang, ${ }^{5}$ Sung Eun \\ Kim, ${ }^{6}$ Kyoungwon Jung, ${ }^{6}$ Joon Sung Kim, ${ }^{1}$ Jong Kyu Park, ${ }^{7}$ Ki Bae Bang, ${ }^{8}$ Myong Ki Baeg, ${ }^{9}$ Jeong Eun Shin, ${ }^{8}$ Cheol Min Shin, ${ }^{10}$ \\ Ju Yup Lee, ${ }^{11}$ and Hyun Chul Lim ${ }^{12}$; Functional Dyspepsia Research Group and Clinical Practice Guidelines Group Under the \\ Korean Society of Neurogastroenterology and Motility
}

${ }^{1}$ Department of Internal Medicine, College of Medicine, The Catholic University of Korea, Seoul, Korea; ${ }^{2}$ Department of Internal Medicine, Daegu Catholic University School of Medicine, Daegu, Korea; ${ }^{3}$ Department of Internal Medicine, Ewha Womans University College of Medicine, Seoul, Korea; ${ }^{4}$ Department of Internal Medicine, Konyang University College of Medicine, Daejeon, Korea; ${ }^{5}$ Department of Internal Medicine, Seoul National University Hospital Healthcare System Gangnam Center, Seoul, Korea; ${ }^{6}$ Department of Internal Medicine, Kosin University College of Medicine, Busan, Korea; 'Department of Internal Medicine, Gangneung Asan Hospital, Universityof Ulsan College of Medicine, Gangneung; Gangwon-do, Korea; ${ }^{8}$ Department of Internal Medicine, Dankook University College of Medicine, Cheonan, Chungcheongnam-do, Korea; ${ }^{9}$ Department of Internal Medicine, International St. Mary's Hospital, College of Medicine, Catholic Kwandong University, Incheon, Korea; ${ }^{10}$ Department of Internal Medicine, Seoul National University Bundang Hospital, Seongnam, Gyeonggi-do, Korea; ${ }^{11}$ Department of Internal Medicine, Keimyung University School of Medicine, Daegu, Korea; and ${ }^{12}$ Department of Internal Medicine, Yongin Severance Hospital, Yonsei University College of Medicine, Yongin, Korea

Functional dyspepsia (FD) is a chronic upper gastrointestinal (GI) symptom complex that routine diagnostic work-up, such as endoscopy, blood laboratory analysis, or radiological examination, fails to identify a cause. It is highly prevalent in the World population, and its response to the various available therapeutic strategies is only modest because of the heterogenous nature of its pathogenesis. Therefore, FD represents a heavy medical burden for healthcare systems. We constituted a guideline development committee to review the existing guidelines on the management of functional dyspepsia. This committee drafted statements and conducted a systematic review and meta-analysis of various studies, guidelines, and randomized control trials. External review was also conducted by selected experts. These clinical practice guidelines for FD were developed based on evidence recently accumulated with the revised version of FD guidelines released in 2011 by the Korean Society of Neurogastroenterology and Motility. These guidelines apply to adults with chronic symptoms of FD and include the diagnostic role of endoscopy, Helicobacter pylori screening, and systematic review and meta-analyses of the various treatment options for FD (proton pump inhibitors, H. pylori eradication, and tricyclic antidepressants), especially according to the FD subtype. The purpose of these new guidelines is to aid the understanding, diagnosis, and treatment of FD, and the targets of the guidelines are clinicians, healthcare workers at the forefront of patient care, patients, and medical students. The guidelines will continue to be revised and updated periodically.

\section{(J Neurogastroenterol Motil 2020;26:29-50)}

\section{Key Words}

Dyspepsia; Endoscopy; Evidence-based medicine; Guideline; Proton pump inhibitors

Received: October 29, 2019 Revised: None Accepted: December 8, 2019

(.) This is an Open Access article distributed under the terms of the Creative Commons Attribution Non-Commercial License (http://creativecommons. org/licenses/by-nc/4.0) which permits unrestricted non-commercial use, distribution, and reproduction in any medium, provided the original work is properly cited.

*Correspondence: Joong Goo Kwon and Hye-Kyung Jung are equally responsible for this study. Joong Goo Kwon, MD, PhD Department of Internal Medicine, Daegu Catholic University School of Medicine, 33 Duryugongwon-ro 17-gil, Nam-gu, Daegu 42472, Korea

Tel: +82-53-650-4215, Fax: +82-53-621-4487, E-mail: kwonjg@cu.ac.kr

Hye-Kyung Jung, MD, PhD

Department of Internal Medicine, Ewha Womans University College of Medicine, 1071 Anyangcheon-ro, Yangcheon-gu, Seoul 07985, Korea

Tel: +82-2-2650-2874, Fax: +82-2-2655-2874, E-mail: junghk@ewha.ac.kr 


\section{Introduction}

Functional dyspepsia (FD) is a chronic and recurrent manifestation of gastrointestinal (GI) symptoms in the absence of an organic disease such as peptic ulcer, GI malignancy, gastroesophageal reflux disease, or pancreatitis. Symptoms of FD include epigastric pain, epigastric burning, postprandial fullness, and postprandial satiation. FD is considered a heterogenous condition. According to the Rome III criteria revised in 2006, FD was divided into 2 subtypes, namely, epigastric pain syndrome (EPS) and postprandial distress syndrome (PDS), ${ }^{1}$ and these definition was also adopted by the Rome IV criteria. ${ }^{2}$ Two subtypes of FD were expected to have different pathophysiologies and drug responses. Since the revision of Rome III, many studies have been conducted on this basis, and more research on subtypes of FD has been conducted. The pathophysiology of FD is also heterogenous, and different underlying mechanisms contribute to diverse patterns of symptoms. Impaired gastric accommodation to a meal, delayed gastric emptying, and visceral hypersensitivity are involved in both EPS and PDS, and some patients have an overlap of both subtypes. ${ }^{2}$ Although the Kyoto consensus $^{3}$ suggested Helicobacter pylori eradication as a primary treatment for dyspepsia, accepting this consensus in Korea will require careful consideration because $H$.pylori prevalence in Korea is higher than $50 \%$ in adults ${ }^{4}$ with high resistance rate of antibiotics, ${ }^{5}$ and the efficacy of $H$.pylori eradication therapy for FD symptom resolution is modest.

In 2005, the Korean Society of Neurogastroenterology and Motility (KSNM) published evidence-based guidelines for the diagnosis and treatment of FD. ${ }^{6}$ In 2011, the guidelines were revised through a systematic review that focused on the treatment of FD and have been used in the clinical field. ${ }^{7}$ We introduced the new guidelines for diagnosis and treatment. This included a systematic review of the diagnosis and treatment and meta-analysis, which were performed with regard to FD treatment options such as proton pump inhibitors (PPIs), $H$. pylori eradication, and tricyclic antidepressants (TCAs). These guidelines will be helpful for understanding and treatment of FD.

\section{Revision Process}

\section{Guideline Development Committee}

The steering committee of the KSNM in 2017 undertook the revision of the guidelines. The Working Group for Guidelines De- velopment was formed from 2 of the 12 committees of the KSNM (ie, the FD Research Group and the Clinical Practice Guideline Group). The FD Research Group consisted of 1 institute board member (J.G.K.), 1 staff member (J.H.O.), and 6 general members (C.M.S., J.K.P., K.B.B., J.Y.L, K.J., and C.H.T.). The Clinical Practice Guideline Group consisted of 1 institute board member (H.K.J.), 1 staff member (K.H.S.), and 6 general members (J.E.S., J.S.K, S.J.K, M.K.B., H.C.I., and S.E.K.). The chairman of the Clinical Practice Guideline Group (H.K.J.) supervised and monitored the development process, while a methodologist expert in formulation of guidelines (E.S.S.) conducted the workshop on systematic review and meta-analysis.

\section{Guideline Development Process}

\section{Principles of drafting statements}

The population, intervention, comparator, outcome, and healthcare setting principles were used as the basis of the statements. Current guidelines consist of 2 main topics: diagnosis and treatment of FD. These guidelines were developed by the de novo method that conducted systematic review and meta-analysis for acid suppressants (including PPIs and histamine receptor 2 antagonists $\left.\left[\mathrm{H}_{2} \mathrm{RA}\right]\right), H$. pylori eradication, and TCAs in the management of FD. Subgroup analysis was also performed for the subtypes of FD. Recommendations that were made in previous guidelines but were not supported by medical evidence were revised in English by reinforcing the recent literature.

\section{Systematic review}

Electronic databases, including MEDLINE, Embase, Web of Science, Cochrane Library, and KoreaMed, were searched for relevant literature. Data extraction tables for the main topics (acid suppressants, $H$. pylori) are provided in the supplementary Table (Supplementary Tables 1 and 2). In the review of antisecretory agents, the search keywords were dyspepsia-related index works (Dyspepsia*; Dyspepsie*; Dyspeptic; Indigestion*; Upset stomach; Stomach upset; Apepsy; Apepsia) AND (Proton pump Inhibitor*; Inhibitors, proton pump; Antagonists, histamine $\mathrm{H}_{2}$; Antihistaminics, $\mathrm{H}_{2}$; Blockaders, $\mathrm{H}_{2}$ receptor; Blockaders, histamine $\mathrm{H}_{2}$ receptor; Blockers, histamine $\mathrm{H}_{2} ; \mathrm{H}_{2}$ antagonists, histamine; $\mathrm{H}_{2}$ antihistamin*; $\mathrm{H}_{2}$ blockers, histamine; $\mathrm{H}_{2}$ receptor blockader*; $\mathrm{H}_{2} \mathrm{RA}$; Histamine 2 antagonist*; Histamine $\mathrm{H}_{2}$ antagonist*; Histamine $\mathrm{H}_{2}$ blocker*; Histamine $\mathrm{H}_{2}$ receptor antagonist*; Histamine $\mathrm{H}_{2}$ receptor blockader*; Receptor antagonists, histamine $\mathrm{H}_{2}$; Receptor blockaders, $\mathrm{H}_{2}$ ). In the review of $H$. pylori, the search key words 
were as follows: (Helicobacter Pylori, H. Pylori, Campylobacter Pylori, Helicobacter Infect*, Infect* Helicobacter, Eradicat*, Eradicant*, Eliminat*, Anti Bacterial*, Antibacterial*, Bacteriocid*, Anti-Helicobacter Pylori, Anti-Campylobacter Pylori, Anti-Ulcer Agent*). In the review of TCAs, the search key words were as follows: Antidepressive agents, Serotonin uptake inhibitors, Sulpiride, Mianserin, Desipramine, Imipramine, Trimipramine, Doxepin, Dothiepin, Notriptyline, Amitriptyline, Paroxetine, Sertraline, Fluoxetine, Citalopram, Venlafaxine, Duloxetine, Ecitalopram, Levosulpiride, Mirtazapine, Tricyclic, Desimipramine, Buspirone, Tandospirone). The full literature search strategy is provided as supplementary. The inclusion criteria were: adult (over 19 years of age), literature from 2005 to the present, literature written in English or Korean, and randomized controlled studies. The exclusion criteria were: outcome of interest not reported; narrative review, editorial, guidelines, or not randomized trial; and studies conducted in healthy volunteers. We critically appraised the quality of selected studies using risk of bias tools. We used the Cochrane Risk of bias for randomized controlled trials (RCTs). ${ }^{8}$ Researchers independently assessed the studies and disagreement were resolved by discussions and 3rd member of opinion (Supplementary Fig. 1-8).
We also conducted a literature search on the patients' preferences. Results of symptom survey of FD patients via computer-assisted personal interview, which results in drug use in FD patients, were in order of "epigastric pain," "acid reflux/indigestion," and "time to onset of action."

\section{Level of evidence and grade of recommendation}

This revision defines 4 levels of evidence and evaluates the level of evidence for each statement based on the modified Grading of Recommendations Assessment, Development, and Evaluation (GRADE) (Table 1). ${ }^{10}$ Grading of recommendation also modified GRADE methodology as 5 levels including; strong for, weak for, weak against, strong against, and no recommendation (Table 2). ${ }^{10}$ We considered evidence level, clinical applicability, benefit and harm as recommendation factors. The Committee reviewed the draft of the working group then discussed for consensus.

\section{Expert consensus by Delphi agreement process}

To adopt the core recommendations of the guidelines, the Delphi technique, which is a panel of experts on FD, was used. The panel was selected by former or current members of the KSNM

Table 1. Level of Evidence

\begin{tabular}{ll}
\hline \multicolumn{1}{c}{ Class } & \multicolumn{1}{c}{ Explanation } \\
\hline High & At least one RCT or SR/meta-analysis with no concern of study quality \\
Moderate & At least one RCT or SR/meta-analysis with minor concern of study quality or \\
& At least one cohort/case-control/diagnostic test design study with no concern of study quality \\
Low & At least one cohort/case-control/diagnostic test study with minor concern of study quality or \\
& At least one single arm before-after study, cross-sectional study with no concern of study quality \\
Very low & At least one cohort/case-control/diagnostic test design study with serious concern of study quality or \\
& At least one single arm before-after study, cross-sectional study with minor/severe concern of study quality
\end{tabular}

$\mathrm{RCT}$, randomized controlled trials; SR, systemic review.

Table 2. Grading of Recommendations

\begin{tabular}{|c|c|}
\hline Grade classification & Explanation \\
\hline Strong for & $\begin{array}{l}\text { The benefit of intervention is greater than harm with high or moderate level of evidence, which can be strongly recom- } \\
\text { mended in most clinical practice }\end{array}$ \\
\hline Weak for & $\begin{array}{l}\text { The benefit and harm of intervention may vary depending on the clinical situation or patient/social value. It is recom- } \\
\text { mended conditionally according to the clinical situation. }\end{array}$ \\
\hline Weak against & $\begin{array}{l}\text { The benefit and harm of intervention may vary depending on the clinical situation or patient/social value. Intervention } \\
\text { may not be recommended in clinical practice }\end{array}$ \\
\hline Strong against & $\begin{array}{l}\text { The harm of intervention is greater than the benefit with high or moderate level of evidence, intervention should not rec- } \\
\text { ommended in clinical practice }\end{array}$ \\
\hline No recommendation & $\begin{array}{l}\text { It is not possible to determine the recommendation direction owing to a lack of evidence or discrepancy of result. Thus } \\
\text { further evidence is needed. }\end{array}$ \\
\hline
\end{tabular}


Steering Committee and the faculty of gastroenterology departments of university hospitals. The first Delphi round was conducted on the 9 newly updated recommendations, including 2 diagnostic methods (endoscopy and $H$. pylori screening) and 7 treatment modalities (including PPIs, prokinetics, eradication of $H$. pylori infection, antipsychotics, gastromucosal protective agents, and simethicone). The definition of agreement or other methods are the same as the previous guidance development method. ${ }^{11}$ A total of 27 doctors participated in the first round of Delphi consensus. Specific methods, such as the criteria for consent, were the same as for the previous guidelines. Out of a total of 14 statements, we voted on 9 covering recent research, of which, 2 statements about gastromucosal protective agents and simethicone were not accepted, while the other 7 were.

\section{Internal and external reviews}

Guideline development committee members conducted internal reviews through online and offline meetings. KSNM executives completed internal review by creating additional amendments. The Korean Society of Internal Medicine recommended members who acted as external judges (S.C.C. and M.I.P). According to the external review, the definition of FD and the change in terminology were pointed out and modified. In addition, an explanation on the difference between the international trend including the Kyoto consensus and Korean guidelines was added.

\section{Dissemination of the guidelines and revision plans}

The developed guidelines will be listed in the "Clinical practice guidelines" on the official website of the Korean Society of Gastroenterology. In addition, these latest guidelines will be presented at medical symposia, conferences, and hospitals. Amendment to these new guidelines is scheduled to be made in about 5 years if the data are accumulated. The relevant committee of KSNM will be responsible for the revision.

\section{Editorial independence}

These guidelines were developed independently by KSNM without external funding, and KSNM did not have any specific impact on the development process of working teams. No other organization or individual influenced the content of the guidelines. No member of the working team has a conflict of interest, which has been documented.

\section{Definition of Dyspepsia}

Dyspepsia is defined as any symptom that refers to the upper GI tract, and it is one of the most common GI symptom. FD is defined by the Rome IV criteria as a syndrome with one or more of the following symptoms present over the past 3 months, with at least 6 months of onset: bothersome postprandial fullness, early satiation, epigastric pain, and epigastric burning, with no evidence of structural disease, as seen in upper endoscopy that is likely to explain the symptoms. ${ }^{2}$ The Rome criteria have the advantage of selecting the more homogenous subset from various dyspeptic patients in actual clinical practice. In the National Institute for Health and Care Excellence guidelines and American College of Gastroenterologists \& Canadian Association of Gastroenterologists clinical guidelines on dyspepsia management, dyspepsia is defined as predominant epigastric pain lasting at least 1 month and associated with any other upper GI symptom such as epigastric fullness, nausea, vomiting, or heartburn. ${ }^{12,13}$ These guidelines are intended to be used in clinical practice and are intended to target a wide range of dyspeptic patients beyond those that meet the definition of FD by Rome criteria. Thus, in the presently proposed guideline, dyspepsia is defined as pain or discomfort in the upper abdomen, postprandial fullness, early satiation, bloating, nausea, or vomiting that has lasted more than 1 month.

Refractory FD refers to FD that has continuous symptoms for at least 8 weeks and has been unresponsive to at least 2 medical treatments. ${ }^{14}$ The guidelines for FD in the Asia-Pacific region and the United States of America (USA) recommend changing to a different drug if adequate therapeutic efficacy has not been achieved after 4 weeks of treatment. ${ }^{15,16}$ Recent Japanese guideline for dyspepsia suggested that refractory FD is one that did not respond to initial treatment with acid suppressants and prokinetics, and second step of treatment with traditional medicine, anxiolytics or antidepressants, and $H$. pylori eradication. ${ }^{14}$ Before diagnosing refractory FD, other organic diseases, including pancreatic diseases, gall bladder dysfunction or other biliary diseases, should be also excluded.

\section{Diagnosis of Functional Dyspepsia}

\section{Esophagogastroduodenoscopy}

Statement 1: Prompt upper GI endoscopy is recommended in dyspeptic patients aged 40 years or older to exclude organic disor- 
der, including upper gastrointestinal malignancy.

\section{Grade of recommendation: strong}

Level of evidence: low

Experts' opinions: completely agree, $70.4 \%$; mostly agree, $29.6 \%$; partially agree, $0.0 \%$; mostly disagree, $0.0 \%$; completely disagree, $0.0 \%$; and not sure, $0.0 \%$.

Several studies have shown no significant differences in controlling dyspeptic symptoms between " $H$. pylori test and treat approach" and performing early upper GI endoscopy in patients with dyspepsia, and the former option is more cost-effective. ${ }^{17-19}$ Studies comparing empiric acid suppression therapy with early endoscopy also showed similar outcomes. ${ }^{20,21}$ However, most of these studies were conducted in Western countries. In Asia, the incidence of gastric cancer is very high, and the age of onset is younger than in Western countries. A retrospective study of 14101 patients who have had endoscopy for dyspepsia in China reported that 13 cases (72.2\%) among 18 gastric cancers were missed when the $H$. pylori test and treat strategy was applied in dyspeptic patients under 45 years of age and without alarm symptoms (such as weight loss, dysphagia, GI bleeding, iron deficiency anemia, abdominal mass or persistent vomiting). ${ }^{22}$ A prospective Taiwan study of 17894 patients who had upper endoscopy because of uninvestigated dyspepsia reported that $5.3 \%(12 / 225)$ of the gastric cancer patients discovered were less than 45 years of age and did not have alarm symptoms. The study thus recommended that age of 40 might be an optimal age threshold for screening endoscopy for uninvestigated dyspepsia. ${ }^{23}$

The incidence of gastric cancer in Korea is the highest in the world. In the 2008 Korea Central Cancer Registry, the age-specific gastric cancer incidence per 100000 persons were 16.7 males and 16.4 females within the ages of 34-39 years, and 36.3 males and 28.8 females within the ages of 40-44 years. ${ }^{24}$ The age-adjusted incidence rates per 100000 person-year from 1999 to 2010 were 7.40 males and 8.33 females within the ages of 20-39 years, and these increased up to 73.11 males and 35.13 females within the ages of 40-54 years. ${ }^{25}$ Data from GLOBOCAN 2012, produced by the International Agency for Research on Cancer (IARC), showed that the age-standardized incidence rates per 100000 for gastric cancer in Korea were 5.7 within the ages of 15-39 years, and it increased to 30 within the ages of $40-44$ years. There is no study to evaluate the incidence of gastric cancer by age in patients with dyspepsia in Korea. There was no gastric cancer among the 308 patients under 40 years old in a study done to determine the usefulness of $H$. pylori test before endoscopy in 615 Korean patients with dyspepsia. ${ }^{26}$

A systematic review with meta-analysis was recently done to evaluate the appropriateness of prompt endoscopy as an initial strategy for uninvestigated dyspepsia in Asia, giving the high prevalence of $H$. pylori infection and malignancy. Gastric cancer patients younger than 45 years and 35 years were $17.8 \%$ and $3.0 \%$, respectively, among cancer patients. The review thus concluded that the optimal age threshold for endoscopy screening in patients with uninvestigated dyspepsia in Asia might be 35 years. ${ }^{23}$ According to annual report of cancer statistics in Korea in 2014, the percentage of gastric cancer was 1.2\% (353) for cancer patients aged < 35 years, $3.1 \%$ (932) for those aged $<40$ years, and $7.5 \%(2-230)$ for those $<45$ years among the 29854 patients with gastric cancer. Therefore, because of the high probability of gastric malignancy in patients with dyspepsia and over 40 years of age, we suggest that early upper GI endoscopy should be performed in patients with dyspepsia who are aged 40 or over in order to exclude organic causes, including gastric cancer.

\section{Diagnosis of Helicobacter pylori}

Statement 2: Test for $H$. pylori infection is recommended in dyspeptic patients who are not responding to acid suppressants or prokinetics.

\section{Grade of recommendation: weak}

Level of evidence: very low

Multiple factors may be associated with the pathophysiology of FD. These factors can include impaired gastric accommodation, delayed gastric emptying, hypersensitivity, social factors, $H$. pylori infection, gastric acid secretion, genetic factors, psychological factors, history of infectious colitis, lifestyle, and morphology of the stomach. ${ }^{27}$ The role of $H$. pylori infection in FD has not been fully identified. It has been speculated that $H$. pylori infection causes inflammation of the gastric mucosa, and is associated with specific disturbances of gastric secretory or motor function, which, in turn, may contribute to dyspeptic symptoms. ${ }^{28}$ Approximately $50.0 \%$ of FD patients also have gastritis associated with $H$. pylori. As $H$. pylori infection has been found to be related with GI diseases, many investigators have tried to treat FD by eradication of the infection. A systematic review concluded that there was a small but statistically significant benefit of treating $H$. pylori infection in patients with $\mathrm{FD} .{ }^{29}$ In $17 \mathrm{RCT}$ comprising over 3500 patients, the relative risk (RR) reduction seen with treatment of $H$. pylori infection was $10.0 \%$ (95\% confidence interval [CI], 6.0-14.0\%) and the number needed to treat (NNT) to cure one patient with FD was 14 (95\% CI, 10-25). In the United Kingdom (UK), the Bristol Helicobacter Project randomized 1517 H. pylori-positive adults under 60 
years of age to undergo treatment for $H$. pylori infection or placebo and followed them up prospectively. ${ }^{30}$ Among those treated for the infection, of whom over $90.0 \%$ achieved successful eradication, there was a small but statistically significant $(P<0.05)$ reduction in subsequent consultations at the primary care level for dyspeptic complaints. In Korea, the prevalence of $H$. pylori decreased significantly from $59.6 \%$ in 2005 to $51.0 \%$ in 2015 , and this change was more pronounced among younger age groups under forties. ${ }^{31}$ The prevalence in Western countries is around $20.0 \%$ and $40.0 \%$ among young adults and at older ages, respectively. ${ }^{32}$

The prevalence of gastric cancer is high in Asian countries, including Korea, particularly among young people. Long-term empirical drug treatment as the initial approach to dyspepsia is not advisable because of delay in the diagnosis of organic disease, especially in patients with dyspepsia over 40 years of age, in whom there is high probability of gastric cancer. Therefore, we suggest that "test and treat approach" for $H$. pylori may be considered in dyspeptic patients under 40 years without alarm symptoms.

Urea breath tests and stool antigen tests are the most widely used noninvasive tests for $H$. pylori infection, whereas serology is useful in screening and epidemiological studies. The ${ }^{13} \mathrm{C}$-urea breath test and the stool antigen test provide $90.0 \%$ sensitivity and specificity, and the ${ }^{13} \mathrm{C}$-urea breath test is widely used in clinical practice. Serologic tests detecting IgG antibodies against $H$. pylori should be used and interpreted with caution as the antibodies can persist sometimes for years, and a positive test may only indicate past infection. In addition, when upper GI endoscopy is undertaken in patients with dyspepsia, rapid urease tests or histological examination using gastric biopsy samples could also be performed to check for $H$. pylori infection.

\section{Alarm Symptoms}

Statement 3: When dyspepsia is accompanied by the following alarm symptoms, signs or medical history, further evaluation should be considered: age $>40$ years, abnormal weight loss, progressive dysphagia, bleeding signs, persistent vomiting, family history of gastric cancer, and recent non-steroidal anti-inflammatory drug (NSAID)/anticoagulant/antiplatelet agent use.

\section{Grade of recommendation: strong \\ Level of evidence: low}

FD is diagnosed by both the presence of typical symptoms and the exclusion of organic diseases such as gastric cancer. Several guidelines have recommended evaluation of organic causes when alarm features (eg, weight loss, bleeding signs, progressive dysphagia, persistent vomiting, and recent NSAID/anticoagulant/ antiplatelet use) are present. ${ }^{14,16,33,34}$ However, a recent systematic review found that alarm symptoms were of limited value in detecting organic pathology. ${ }^{35}$ This has led to a revised guideline, which recommends further evaluation in patients with alarm symptoms and over the age of 60 years or those with symptoms that suggest a pancreatic or biliary source. ${ }^{36}$

However, this fails to take into account the epidemiologic differences in organic disease between the East and West. Gastric cancer is highly prevalent in Korea and is projected to be the most commonly diagnosed cancer in men between 35 years and 50 years of age and the third most diagnosed cancer in women of the same age range. ${ }^{37}$ Furthermore, a recent systematic review found that alarm symptoms in young Asians were of significant diagnostic value. ${ }^{38}$ Therefore, we suggest that dyspeptic patients with alarm symptoms undergo further evaluation such as upper GI endoscopy, regardless of age. However, we agree with previous guidelines that suggest no further evaluation for patients with intractable dyspepsia without alarm signs as such evaluation may be of limited clinical benefit. ${ }^{36}$

Patients with continued symptoms of dyspepsia should be carefully reassessed, paying specific attention to the type of ongoing symptoms, and the degree to which symptoms have improved or worsened. If clinically indicated, complete blood count (CBC) and blood chemistry should be performed in dyspeptic patients to identify organic diseases that can cause dyspepsia. ${ }^{14,39}$ The development of iron deficiency anemia has been found to be a predisposing factor for the diagnosis of pathologic GI diseases. Pathologic GI diseases was diagnosed in $23.0 \%$ of Korean adult population who presented with iron deficiency, and GI malignancy was diagnosed in $1.0 \%$ of that population, mainly in elderly patients. ${ }^{40}$ In that study, it was suggested that patients with iron deficiency should undergo endoscopic evaluation of the GI tract, irrespective of whether or not they have anemia. ${ }^{39}$ Anemia is also associated with $H$. pylori infection. $\mathrm{Qu}$ et al conducted a meta-analysis of 15 case-control studies to investigate the relationship between $H$. pylori infection and iron deficiency anemia (IDA). The data showed an increased risk of IDA in patients with $H$. pylori infection with an odds ratio $(\mathrm{OR})$ of 2.2 (95\% CI, 1.5-3.2). ${ }^{41}$ Therefore, current international and national guidelines recommend eradication of $H$. pylori infection in patients with unexplained IDA. ${ }^{42,43}$

Patients with unresponsive to empirical medical therapy should undergo blood tests, such as CBC and blood chemistry, if not conducted at the time of initial diagnosis. Upper abdominal ultrasonography or abdominal CT scan may be employed, especially in areas with high prevalence of liver ${ }^{44}$ or pancreatic cancers that pres- 
ent with dyspeptic symptoms. ${ }^{14,36,39,44}$

\section{Treatments}

\section{Acid Suppressants}

\section{Proton pump inhibitors}

Statement 4: PPIs are recommended for the treatment of FD.

Grade of recommendation: strong

Level of evidence: high

Experts' opinions: completely agree, $44.5 \%$; mostly agree, $37.0 \%$; partially agree, $14.8 \%$; mostly disagree, $3.7 \%$; completely disagree, $0.0 \%$; and not sure, $0.0 \%$.

Hypersensitivity to acid, reduced duodenal acid clearance, and altered gastric motility induced by duodenal acid have been suggested as putative roles of acid in FD and justification for the use of acid suppressive therapy. ${ }^{45-47}$ PPIs have been the mainstay treatment for FD, but the reported efficacy is marginal and controversy exists. ${ }^{48}$ We performed a new meta-analysis to investigate the efficacy of PPI therapy (Supplementary Fig. 1-3). We identified 8 RCTs involving $2216 \mathrm{FD}$ patients to compare the global symptom improvement between PPI and placebo. ${ }^{49-56}$ The treatment period was 2-8 weeks. PPI was more effective than placebo for overall global symptom improvement, with symptom improvement seen in $36.0 \%$ of the PPI group and $30.0 \%$ of the placebo group (RR, 1.41; $95 \%$ CI, 1.07-1.87). However, there was heterogeneity between studies $\left(\chi^{2}=17.76 ; P=0.01 ; I^{2}=61 \%\right.$ ) (Fig. 1$)$. The NNT was 9 (95\% CI, 6-24). In subgroup analysis, PPI was effective in terms of symptom relief (RR, 1.44; 95\% CI, 1.03-2.01) and complete relief of global symptom (RR, 1.26; 95\% CI, 1.07-1.49) (Fig. 2).
Subgroup analyses were performed according to the treatment duration. Three RCTs evaluating the efficacy of PPI after 8 weeks of treatment demonstrated statistically significant symptom relief with PPI therapy in FD patients (RR, 1.24; 95\% CI, 1.03-1.49) with no heterogeneity $\left(\chi^{2}=0.33 ; P=0.85 ; \mathrm{I}^{2}=0 \%\right)$. However, there was no significant difference in efficacy between PPI and placebo in $\leq 4$ weeks treatment duration (RR, 1.40; 95\% CI, 0.99-1.97) (Fig. 3).

Statement 5: PPIs should be recommended as a first-line treatment for FD in patients with EPS.

Grade of recommendation: strong

Level of evidence: moderate

Experts’ opinions: completely agree, 25.9\%; mostly agree, $55.6 \%$; partially agree, $18.5 \%$; mostly disagree, $0.0 \%$; completely disagree, $0.0 \%$; and not sure, $0.0 \%$.

PPIs are believed to be effective for FD patients with ulcer or reflux-like symptoms, ${ }^{57}$ and several guidelines suggest tailored PPIs treatment according to FD subtype. ${ }^{58-60}$ However, this is controversial. ${ }^{61-63}$ Although the Rome III criteria subdivided FD into EPS and PDS, dyspepsia forms a symptom complex with overlap between EPS and PDS. ${ }^{27,64}$ We identified 4 RCTs that evaluated the efficacy of PPI in FD patients with epigastric pain or burning as the predominant symptom, including 2 involving the EPS subtype based on the Rome III criteria. ${ }^{51,52,54,55}$ PPI was more effective than placebo for the treatment of predominant epigastric pain or burning $(\mathrm{RR}=1.22 ; 95 \% \mathrm{CI}=1.04-1.44)$ with no observed heterogeneity $\left(\chi^{2}=0.02, P=0.99, \mathrm{I}^{2}=0 \%\right)$. Regarding postprandial fullness or early satiation as the predominant symptom, there were $2 \mathrm{RCT}$ that defined the PDS subtype. ${ }^{54,55}$ No significant difference was observed between the PPI and placebo groups in patients with the PDS subtype $(\mathrm{RR}=1.56$; 95\% CI $=0.91-2.70)$ without hetero-

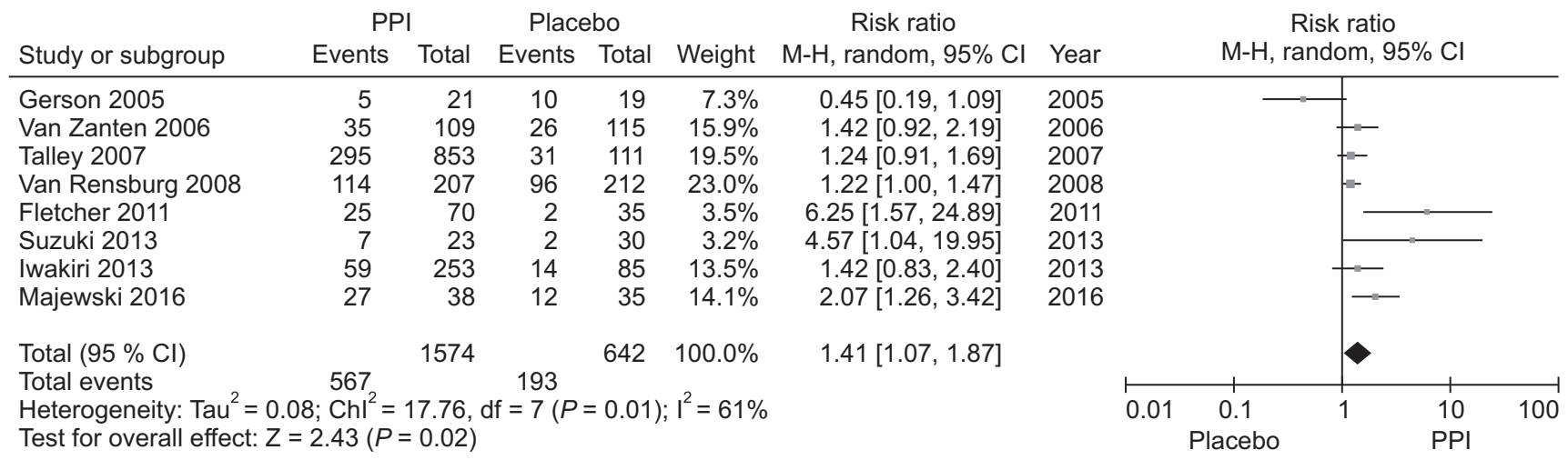

Figure 1. Forest plot of randomized controlled trials comparing proton pump inhibitors (PPIs) with placebo in patients with functional dyspepsia. 


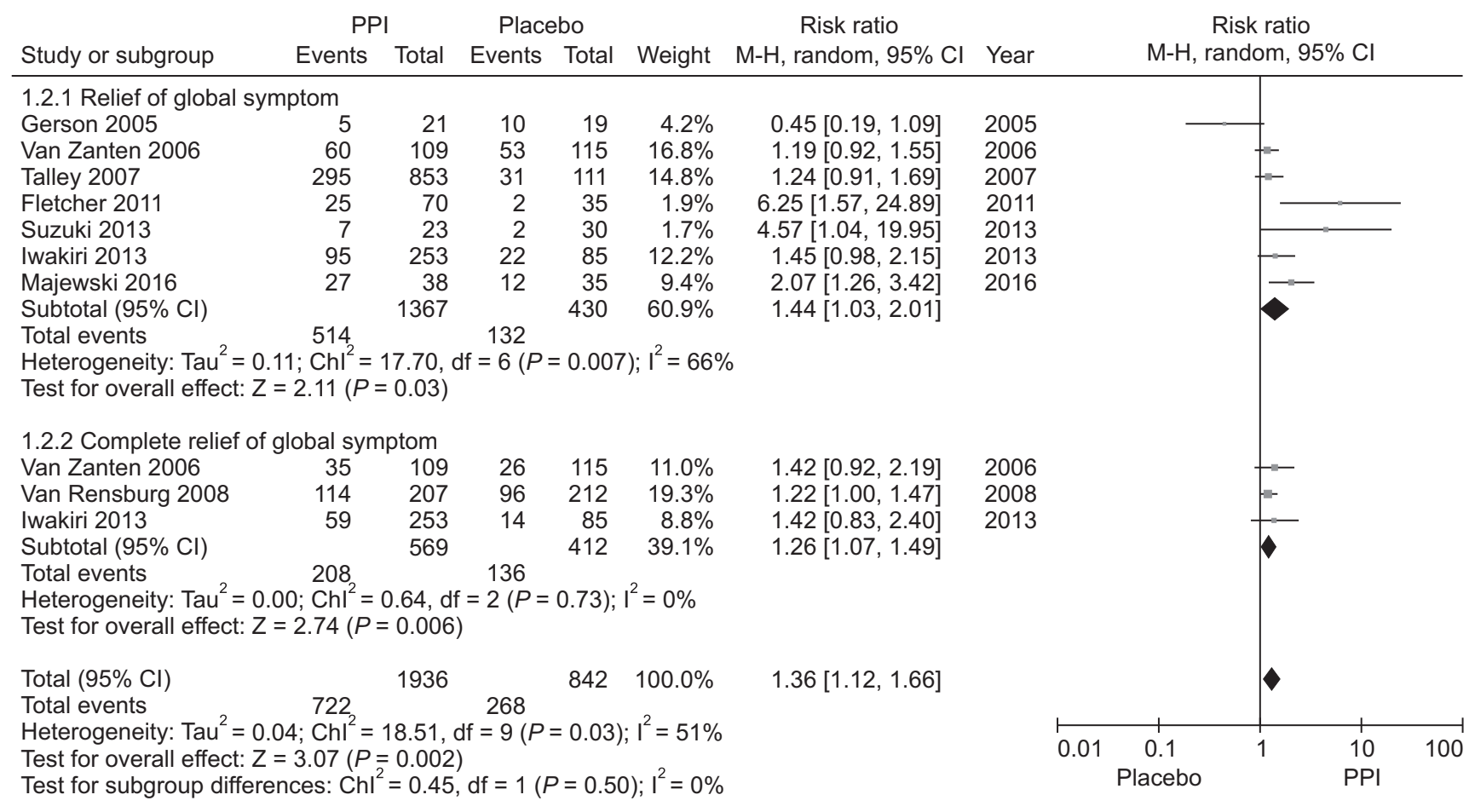

Figure 2. Forest plot of randomized controlled trials comparing proton pump inhibitors (PPIs) with placebo in patients with functional dyspepsia according to the relief of global symptom.

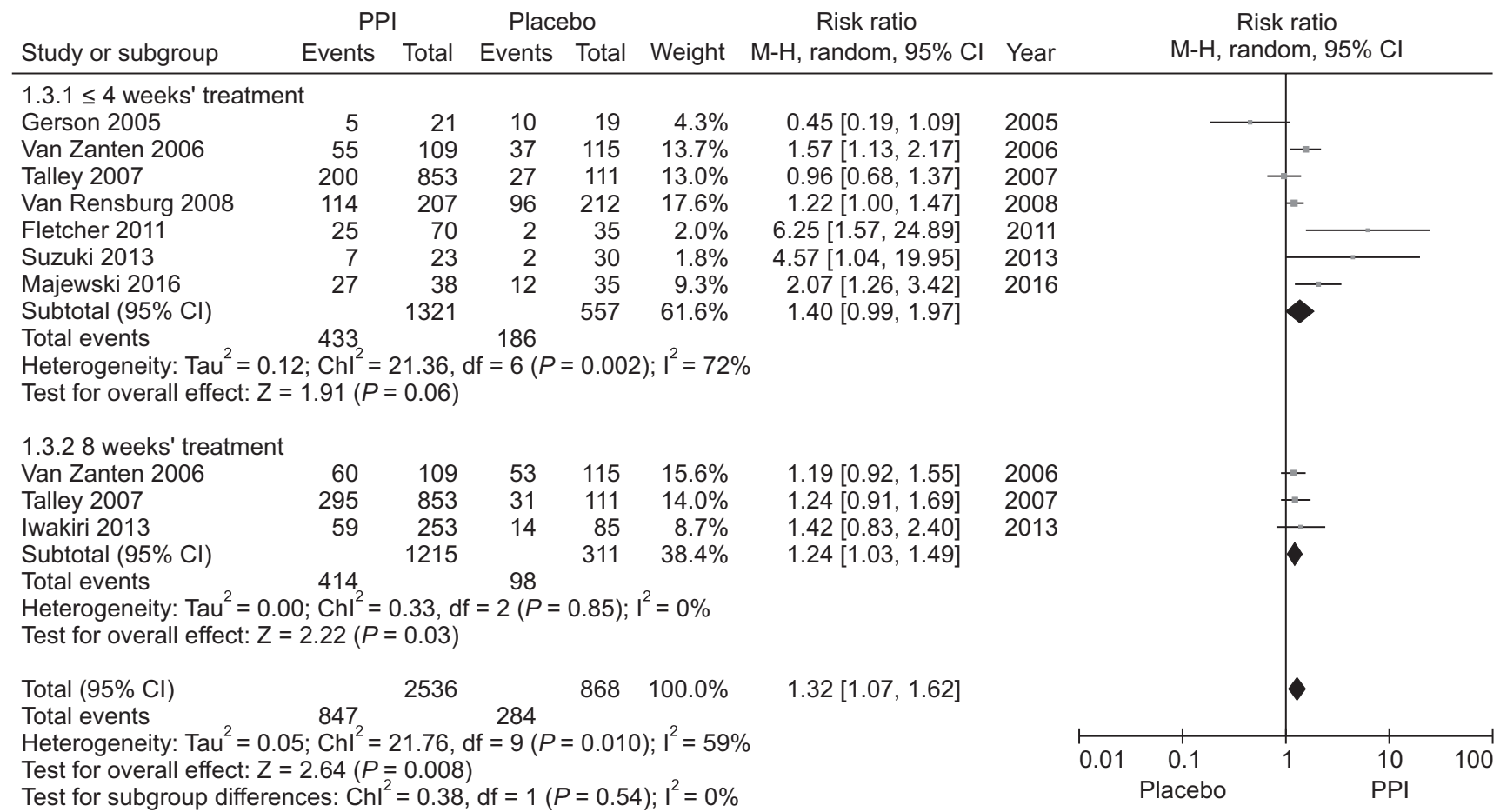

Figure 3. Forest plot of randomized controlled trials comparing proton pump inhibitors (PPIs) with placebo in functional dyspepsia patients according to the treatment duration. 
geneity (Fig. 4). However, further studies are required due to the paucity and heterogeneity of the included studies. We downgraded the quality of evidence due to the application of inconsistent diagnostic criteria for FD among the included studies. Although the level of evidence is not high, it could be useful as first-line treatment for patients with EPS symptoms.

\section{Histamine type 2 receptor antagonists}

Statement 6: $\mathrm{H}_{2} \mathrm{RAs}$ are reasonable treatment in functional dyspepsia, especially for short-term use.

Grade of recommendation: weak

Level of evidence: moderate

$\mathrm{H}_{2} \mathrm{RAs}$, as acid suppressants, are another option for the treatment of FD. A Cochrane meta-analysis of 12 RCTs involving 2456 non-ulcer dyspeptic patients reported an RR of persistent symptoms of 0.77 (95\% CI, 0.65-0.92) and an NNT of 7. However, the evidence justifying the use of $\mathrm{H}_{2} \mathrm{RAs}$ is limited. The overall quality of the trials was low, and they were conducted before the introduction of the Rome III criteria. ${ }^{65}$ Regarding the efficacy of $\mathrm{H}_{2} \mathrm{RAs}$ compared with PPI, there was no statistical difference in terms of symptom relief in a recent meta-analysis of $7 \mathrm{RCT}$ evaluating 2456 dyspeptic patients (RR, 0.93; 95\% CI, 0.76-1.16). However, there was a trend toward greater symptom relief with a PPI among the included studies. ${ }^{36}$ Moreover, repeat dosing of $\mathrm{H}_{2} \mathrm{RAs}$ led to the development of tachyphylaxis or tolerance, ${ }^{66}$ thus attenuating their efficacy but without further reduction in efficacy once tachyphylaxis had been developed. ${ }^{67}$ Tachyphylaxis possibly limits the use of $\mathrm{H}_{2} \mathrm{RAs}$ as maintenance therapy for FD due to attenuated efficacy. ${ }^{68}$ Although $\mathrm{H}_{2} \mathrm{RAs}$ are considered safe, they can cause adverse drug reactions (ADRs), including anaphylaxis. In a study evaluating 584 patients (694 cases) with ADRs caused by ranitidine, anaphylaxis was occasionally observed. ${ }^{69}$ Besides, ranitidine metabolite from several manufacturers has been reported to have a carcinogenic property in September 2019, then, many drugs including ranitidine have been withdrawn from the market. Thus, while short-term use of $\mathrm{H}_{2} \mathrm{RAs}$ may be indicated in the management of FD, caution may need to be taken.

\section{Prokinetics}

Statement 7: Prokinetics are effective in the treatment of FD.

Grade of recommendation: strong

Level of evidence: moderate

Experts' opinions: completely agree, $35.7 \%$; mostly agree, $53.6 \%$; partially agree, $10.7 \%$; mostly disagree, $0.0 \%$; completely disagree, $0.0 \%$; and not sure, $0.0 \%$.

Prokinetic drugs are classified as dopamine $\mathrm{D}_{2}$ receptor antagonists ( $\mathrm{D}_{2}$ antagonists), 5-hydroxytryptamine $4\left(\mathrm{HT}_{4}\right)$ receptor agonists, or motilin agonists, based on their mechanism of action.

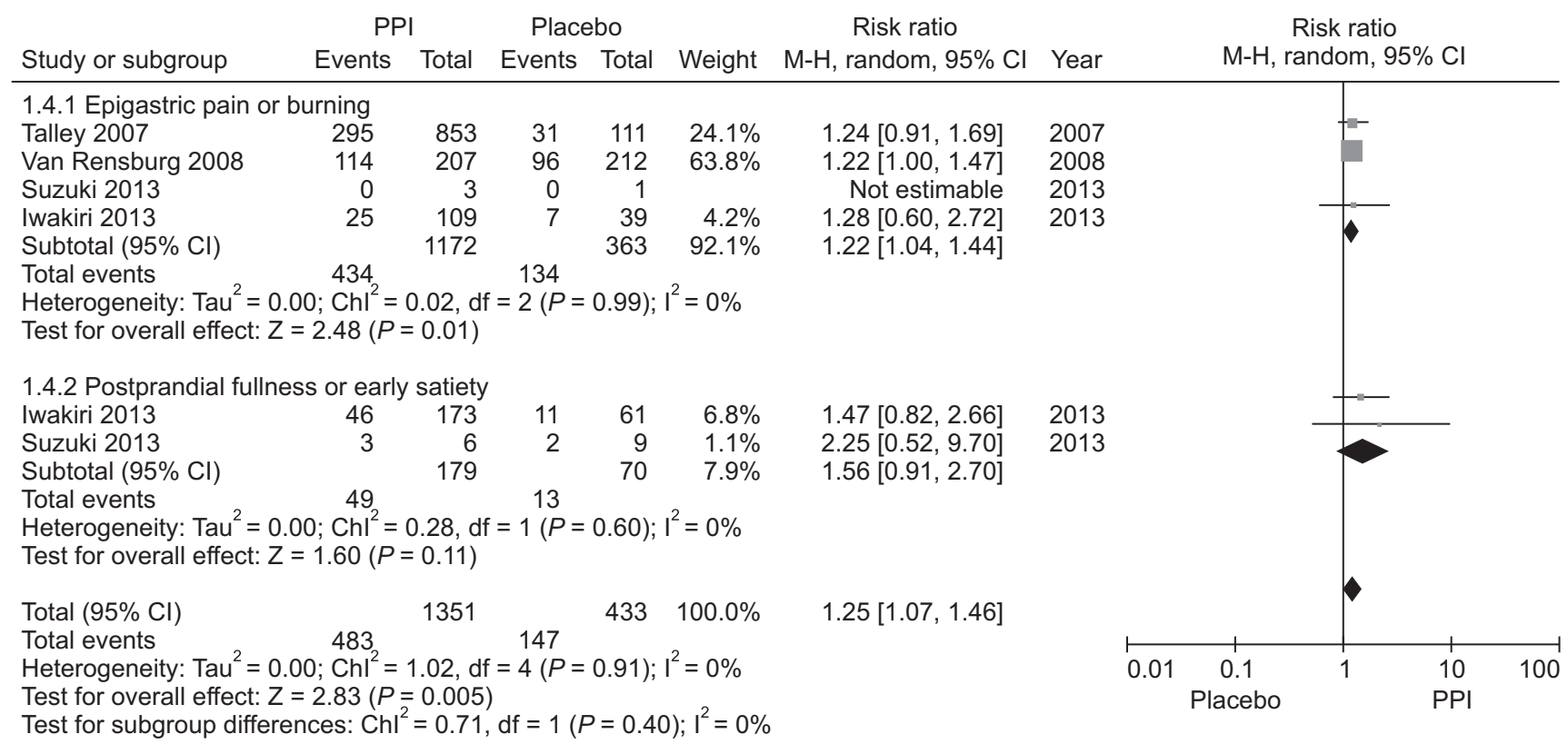

Figure 4. Forest plot of randomized controlled trials comparing proton pump inhibitors (PPIs) with placebo in functional dyspepsia patients according to the predominant symptom. 
Domperidone, a $\mathrm{D}_{2}$ antagonist, was found in a meta-analysis to be effective for the treatment of bloating and early satiation symptoms as compared to placebo when used for 2-4 weeks. ${ }^{70}$ Metoclopramide and levosulpiride have also been shown to improve dyspeptic symptoms. ${ }^{71}$ However, metoclopramide, levosulpiride, and domperidone, which are effective $\mathrm{D}_{2}$ antagonists, may cause extrapyramidal symptoms, and this limits their dosing duration in Korea.

Itopride is a $\mathrm{D}_{2}$ antagonist that works peripherally, avoiding the central receptor-related extrapyramidal side effects and resulting in a minimal elevation of prolactin hormone levels. It was found to be effective for global symptom improvement, postprandial fullness, and early satiation when compared to placebo in a meta-analysis comprising 9 studies that included a total of 2620 patients. $^{72} \mathrm{Al}$ though this drug is not available in the USA or UK owing to negative phase III study results, ${ }^{73}$ it can be used in Korea.

Representative $5-\mathrm{HT}_{4}$ receptor agonists, cisapride and tegaserod, have been reported to induce arrhythmias and cardiovascular disease. Therefore, these drugs have been excluded from the current market. Mosapride, another $5-\mathrm{HT}_{4}$ receptor agonist, does not induce arrhythmia, and promotes GI motility and gastric emptying. ${ }^{74}$ Similar to itopride, mosapride did not show superior results compared with placebo in a RCT of FD, but in one study it was found to improve overall quality of life. ${ }^{75,76}$ Furthermore, in a recent meta-analysis with $13 \mathrm{RCTs}$, mosapride did not show a consistent benefit, although the diagnostic criteria were different for each study. ${ }^{77}$ Conversely, in a sensitivity meta-analysis of 4 high-quality RCTs, mosapride was found to be an effective drug for FD (RR, 1.114; 95\% CI, 1.011-1.227; $P=0.029) .^{77}$ Therefore, considering that serotonin receptor agonists have been effective in previous studies of FD and that mosapride continues to be used in clinical practice with no side effects related to arrhythmia, it could be a good option for the treatment of patients with FD. ${ }^{78-80}$

Recently, a sustained-release, once-daily mosapride formulation was developed (a reduction from the conventional thrice-daily dosing regimen). According to a recent report, 138 patients were enrolled and divided into 2 groups (a study group and a conventional control group). When the improvement of GI symptoms and side effects were compared, the once-daily sustained-release group was not inferior to the conventional mosapride dosing group. Considering the ease of compliance, the once-dosing medication regimen will be a good choice in the future. ${ }^{81}$

A meta-analysis in 2007, which tested various prokinetics, showed a $30 \%$ higher probability of obtaining a treatment effect with prokinetics as compared with placebo (95\% CI, 0.208-0.382; $P<0.001)$. However, the most widely tested drug was cisapride, which has been discontinued due to its side effects. ${ }^{82}$ Similarly, in a recent meta-analysis of 38 studies, although with low quality of evidence, prokinetics significantly reduced overall symptoms of FD compared to placebo (NNT $=7$ ). However, there was no difference in quality of life or adverse effect. ${ }^{83}$ In addition, in a recently reported meta-analysis with 4473 patients in $25 \mathrm{RCTs},{ }^{83}$ it was demonstrated that currently used prokinetics were more effective than placebo, using a Bayesian method network analysis. In particular, metoclopramide, trimebutine, mosapride, and domperidone were shown to have better efficacy than itopride or acotiamide, using a league-to-league analysis. ${ }^{84}$

In addition, DA-9701 (motilitone) is a newly developed prokinetic product that is formulated from the plant extracted of Pharbitidis semen and Corydalis tuber. In a study in which 389 patients were divided into 3 groups (motilitone-treated, PPI-treated, and PPI with motilitone-treated), all 3 groups showed significant improvement in dyspeptic symptoms and in quality of life measurements. ${ }^{85}$ However, there was no difference among the groups except for the status of $H$. pylori. Of the $H$. pylori-positive patients, the improvement of dyspeptic symptoms was significantly higher in the PPI alone group or in the PPI with the motilitone group than in the motilitone alone group. ${ }^{85}$ For patients with poor symptom control, increasing the dose of prokinetics or combining 2 types of prokinetic agents, such as metoclopramide and domperidone, was found to be effective. ${ }^{86,87}$ Mechanisms, doses, special comments, and adverse effects of prokinetics for FD are summarized in Table 3.

Statement 8: Prokinetics can be useful as a first-line treatment for $\mathrm{FD}$ in patients with $\mathrm{PDS}$.

\section{Grade of recommendation: strong}

Level of evidence: low

Experts' opinions: completely agree, $32.2 \%$; mostly agree, $60.7 \%$; partially agree, $7.1 \%$; mostly disagree, $0.0 \%$; completely disagree, $0.0 \%$; and not sure $0.0 \%$.

According to the recent Rome IV classification, a large number of FD patients have PDS, which causes discomfort after meals or a feeling of early satiation. ${ }^{88}$ In a large-scale study of mosapride in Japan, ${ }^{78}$ patients with FD were divided into a gastric stasis symptom group and an EPS group. Administration of mosapride led to a significant improvement in the gastric stasis symptom group. However, the control group, which was treated with teprenone, also showed symptomatic improvement, and this is a limitation of the study. In addition, a recent study that used sustained-release mosapride $^{81}$ showed no significant difference in GI symptom score improvement in PDS when patients were sub-grouped by EPS and 
Table 3. Prokinetic Drugs Used in the Treatment of Functional Dyspepsia

\begin{tabular}{|c|c|c|c|c|}
\hline Drug & Mechanism of action & Dose & Special comments & Side effects \\
\hline Levosulpiride & $\begin{array}{l}\text { Dopamine } \mathrm{D}_{2} \text { receptor antagonist, } \\
5-\mathrm{HT}_{4} \text { receptor agonist, weak } \\
5-\mathrm{HT}_{3} \text { receptor antagonist }\end{array}$ & $25 \mathrm{mg}$ tid & $\begin{array}{l}\text { Limited to short duration use for } \\
\text { avoiding side effect }\end{array}$ & $\begin{array}{l}\text { Menstrual abnormalities and } \\
\text { galactorrhea, drug induced par- } \\
\text { kinsonism }\end{array}$ \\
\hline Metoclopramide & $\begin{array}{l}\text { Dopamine } \mathrm{D}_{2} \text { receptor antagonist, } \\
5-\mathrm{HT}_{4} \text { receptor agonist }\end{array}$ & $\begin{array}{l}\text { 5-10 mg tid } \\
\text { (max. } 30 \mathrm{mg} \text { per } \\
\text { day) }\end{array}$ & $\begin{array}{l}\text { Limited to only } 5 \text { day- use/ } \\
\text { treatment, maximal dose: } 0.5 \\
\mathrm{mg} / \mathrm{kg} \text { per day (both adult and } \\
\text { child) }\end{array}$ & $\begin{array}{l}\text { Extrapyramidal symptom, gy- } \\
\text { necomastia, galactorrhea, men- } \\
\text { strual irregularities }\end{array}$ \\
\hline Domperidone & Dopamine $\mathrm{D}_{2}$ receptor antagonist & $\begin{array}{l}10 \mathrm{mg} \text { tid } \\
(\max .30 \mathrm{mg} \text { in } \\
\text { a day) }\end{array}$ & $\begin{array}{l}\text { Limited to one-week use/ } \\
\text { treatment }\end{array}$ & $\begin{array}{l}\text { Gynecomastia, galactorrhea, } \\
\text { menstrual irregularities }\end{array}$ \\
\hline Itopride & $\begin{array}{l}\text { Dopamine } \mathrm{D}_{2} \text { receptor antagonist, } \\
\text { inhibition of acetylcholinesterase }\end{array}$ & $50 \mathrm{mg}$ tid & Not available in the US, UK & Rash, diarrhea, giddiness \\
\hline Mosapride & $5-\mathrm{HT}_{4}$ receptor agonist & $\begin{array}{l}5 \mathrm{mg} \text { tid, } 15 \mathrm{mg} \\
\text { qd }\end{array}$ & $\begin{array}{l}\text { Sustained-release mosapride } \\
\text { (once daily) is available }\end{array}$ & \\
\hline $\begin{array}{l}\text { DA9701 } \\
\text { (Motilitone) }\end{array}$ & $\begin{array}{l}\text { 5- } \mathrm{HT}_{4}, 5-\mathrm{HT}_{1 \mathrm{~A}} \text {, and 5- } \mathrm{HT}_{1 \mathrm{~B}} \\
\text { receptors agonistic effect } \\
\text { Dopamine } \mathrm{D}_{2} \text { receptor } \\
\text { antagonistic effect }\end{array}$ & $30 \mathrm{mg}$ tid & Plant extract & \\
\hline Acotiamide & $\begin{array}{l}\mathrm{M}_{1} \text { and } \mathrm{M}_{2} \text { muscarinic receptors } \\
\text { antagonist }\end{array}$ & $100 \mathrm{mg}$ tid & Not available in Korea & Headache, diarrhea \\
\hline Erythromycin & Motilin receptor agonist & $250-500 \mathrm{mg}$ tid & Not available in Korea & $\begin{array}{l}\text { Arrhythmia, reversible deafness, } \\
\text { abdominal pain, diarrhea }\end{array}$ \\
\hline
\end{tabular}

5-HT, 5-hydroxytryptamine; tid, 3 times a day; qd, once a day.

PDS. A meta-analysis of the previously mentioned itopride showed a significant effect on postprandial fullness and early satiation when compared to domperidone. However, no statistical difference was noted when compared to placebo. ${ }^{72}$

Acotiamide is a newly developed drug that exerts its gastroprokinetic activity by increasing acetylcholine release through antagonism of the $\mathrm{M}_{1}$ and $\mathrm{M}_{2}$ muscarinic receptors in the enteric nervous system and inhibition of acetylcholinesterase activity. ${ }^{89}$ In one RCT, 4 weeks of acotiamide treatment was more effective compared to placebo for the relief of symptom severity and diet-related symptoms. ${ }^{90}$ In another study using acotiamide, a significant effect on gastric accommodation and gastric emptying was noted in $34.8 \%$ of patients. ${ }^{91}$ Additionally, in a meta-analysis of 7 RCT studies, acotiamide was shown to be more effective against PDS-related symptoms compared to placebo. ${ }^{92}$ Acotiamide was also reported to have a significant clinical effect on the quality of life and postprandial symptoms in an open, 3-phase study for long-term outcome and safety. ${ }^{93}$ Recently, a study comparing PDS- and EPS-type patients with FD showed that acotiamide significantly improved symptoms in both groups, but in a subgroup analysis, it was found to be more effective against the PDS type. ${ }^{94}$ Based on these results, acotiamide would be a good therapeutic agent for patients who primarily have PDS symptoms. However, acotiamide is not available in Korea, and studies using other prokinetics have been lacking. In the future, randomized or large-scale studies are needed to determine the effects of other prokinetic agents on PDS subtypes.

Erythromycin, a motilin receptor agonist, was shown to be effective in facilitating gastric emptying, and one study showed that it caused improvements in bloating-related symptoms. ${ }^{95}$ However, a randomized study ${ }^{96}$ did not show any statistical difference compared to placebo, and erythromycin is not currently being used in Korea for this indication. Although well-planned RCT studies are lacking, prokinetics are considered important for symptomatic improvement in patients with PDS symptoms in Korea.

Statement 9: It is reasonable to determine the administration of dopamine antagonists carefully, because prolonged use or administration of these drugs in some vulnerable patients can cause irreversible adverse events.

\section{Grade of recommendation: strong}

Level of evidence: low

Prokinetics that have proven effective over placebo are mostly 
$\mathrm{D}_{2}$ antagonists. They act on the excitatory motor neurons in the digestive tract. There are issues of clinical safety for these $\mathrm{D}_{2}$ antagonists, and these require the attention of prescribing physicians. Metoclopramide is the most well-known neuroleptic $\mathrm{D}_{2}$ antagonist. It can cause extrapyramidal symptoms and is characterized by an acute dystonic reaction within the first 24 hours to 48 hours with a typical adult dose. The risk of extrapyramidal adverse effects increases with duration of treatment and total cumulative dose. These effects are generally irreversible and more prevalent in adolescent patients. ${ }^{97}$

Domperidone may cause QT prolongation and thus cardiac arrhythmias may occur consequently. In 2 case-control studies in 2010, domperidone exposures were significantly higher in patients with sudden death or severe ventricular arrhythmias than in controls. ${ }^{98,99}$ Based on this, the European Medicines Agency recommended limited use of domperidone. In 2014, the Korean Ministry of Food and Drug Safety also sent a letter of safety regarding the use of the drug: the ministry recommended limited use for alleviating nausea or vomiting, emphasizing not to use beyond a dose of 10 mg 3 times a day, for at most 1 week. Concomitant administration of cardiac medications, quinolones, clarithromycin, isoniazid, antifungal agents, and fluoxetine, which may cause QT prolongation, was prohibited.

Data on 132 drug-related movement disorders in one institution showed that the majority (68.9\%) were related to levosulpiride. Most of the patients were relatively elderly patients, aged 60 years or older, and they had Parkinsonism, face dyskinesia, and isolated tremor after 5-10 months of medication. Symptoms continued in about half of the patients even after discontinuation of the drug. ${ }^{100}$

\section{Helicobacter pylori Eradication}

Statement 10: $H$. pylori eradication is a reasonable treatment for dyspeptic patients because eradication therapy can provide longterm relief of dyspeptic symptoms.

\section{Grade of recommendation: weak}

Level of evidence: high

Experts' opinions: completely agree, $18.5 \%$; mostly agree, $55.6 \%$; partially agree, $25.9 \%$; mostly disagree, $0.0 \%$; completely disagree, $0.0 \%$; and not sure $0.0 \%$.

In 2 meta-analyses of the RCTs, a small but statistically significant improvement in the long-term (6 months to 12 months) was observed in the $H$. pylori eradication group, ${ }^{17,101}$ but the effect was not significant in the short-term ( 3 months). ${ }^{101}$ One, including 14 RCTs showed that the improvement in dyspeptic symptoms was better in the eradication group than that in the control group after 12 months; ${ }^{17}$ the other meta-analysis, including 25 RCTs demonstrated the conflicting results. ${ }^{101}$ In addition, the side effects were significantly higher in the eradication group and the quality of life was not significantly improved. ${ }^{101}$ The European, USA, and Canadian guidelines strongly recommend eradicating $H$. pylori as the primary treatment for dyspepsia. ${ }^{12,36}$

We performed meta-analysis of 18 RCTs from January 1997 to December 2017, evaluating the long-term (more than 6 months) effect of $H$. pylori eradication in dyspeptic patients (Table 4 and Supplementary Fig. 4 and 5). ${ }^{102-119}$ There was a statistically significant improvement of dyspeptic symptoms in $H$. pylori eradication group (RR dyspepsia improvement $=1.18 ; 95 \% \mathrm{CI}, 1.07-1.31)$. Heterogeneity among studies was moderate but significant $\left(\chi^{2}=\right.$ 25.7; $\left.P=0.08 ; \mathrm{I}^{2}=34 \%\right)(\mathrm{NNT}=14)$ (Fig. 5). Because of significant heterogeneity among studies, we performed subgroup analysis according to the regions; 5 RCTs from Asia and 13 RCTs from regions outside Asia. $H$. pylori eradication therapy induced statistically significant improvement of dyspeptic symptom (RR dyspepsia improvement $=1.22 ; 95 \% \mathrm{CI}, 1.08-1.38)$ without significant heterogeneity $\left(\chi^{2}=18.1 ; P=0.11 ; \mathrm{I}^{2}=33 \%\right)$ in studies from regions outside Asia. However, meta-analysis of studies from Asia revealed that impact of $H$. pylori eradication therapy on dyspeptic symptom was not statistically significant (RR dyspepsia improvement $=1.10 ; 95 \% \mathrm{CI}, 0.92-1.31)$ and heterogeneity among studies was insignificant $\left(\chi^{2}=5.9 ; P=0.21 ; \mathrm{I}^{2}=32 \%\right)$. Overall, the effectiveness of $H$. pylori eradication in $\mathrm{FD}$ patients was small but statistically significant. Therefore, eradication therapy can be considered for dyspeptic patients. However, NNT was not small and subgroup analysis from studies conducted in Asia was not statistically significant. The prevalence of $H$. pylori in Korea is estimated as $54 \%$ (95\% CI, 50.1-57.8). ${ }^{4} \mathrm{In}$ areas with high $H$. pylori prevalence, the cost and side effects associated with eradication therapy, the risk of emergence of resistant bacteria, and the risk of reinfection are expected to be higher than in areas with low $H$. pylori prevalence. Therefore, further well-designed RCTs on the efficacy of $H$. pylori eradication in FD patients and the benefit and risk of eradication therapy in high $H$. pylori prevalence areas should be performed.

Among dyspeptic patients, factors that predict good response to $H$. pylori eradication include an onset of indigestion within 5 years, erosive gastritis or erosive duodenitis, and microscopic gastritis above moderate degree. ${ }^{102,103}$ However, the relationships between these factors and effectiveness of eradication therapy are discordant among studies. Therefore, further researches are also needed in this area. 


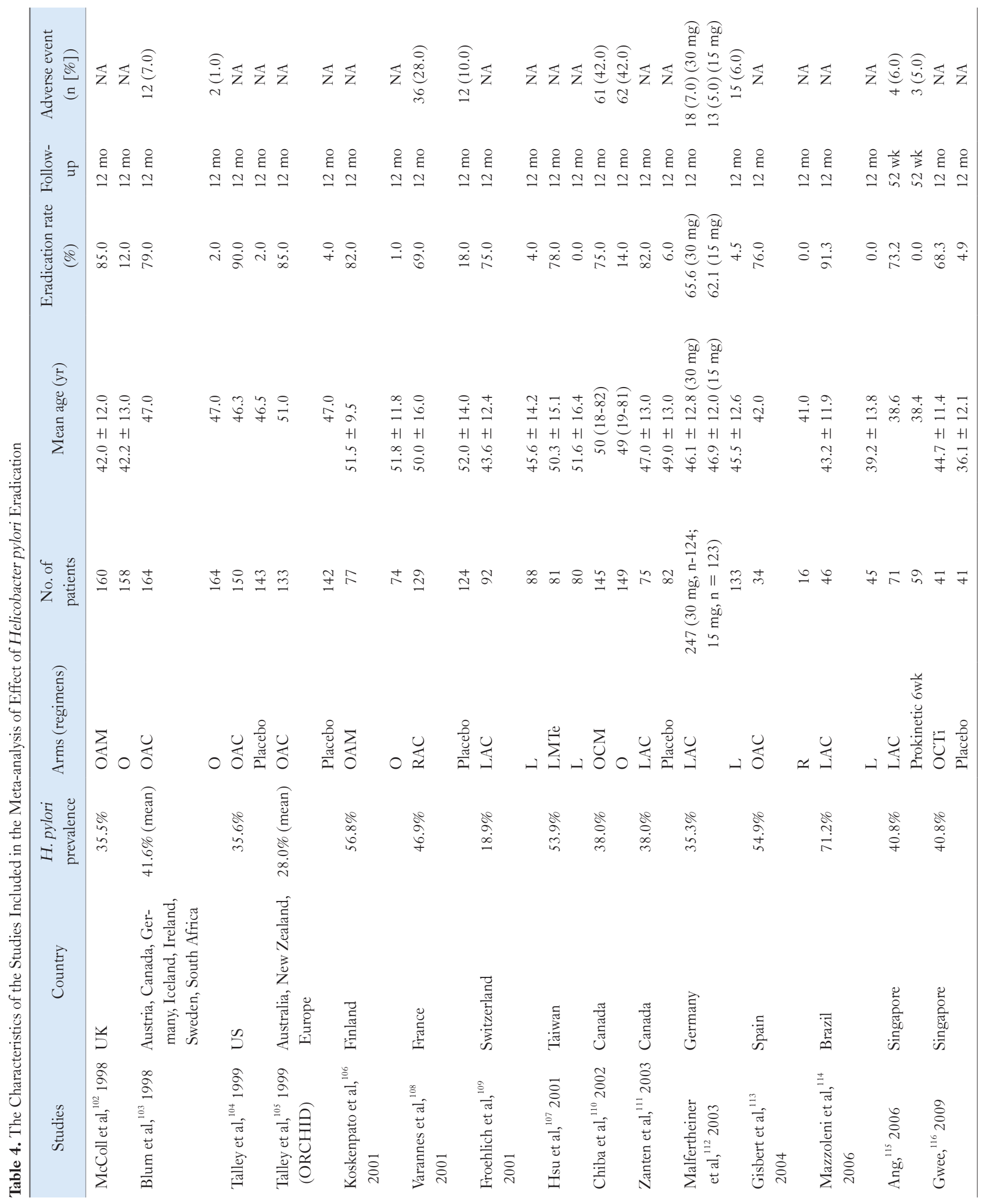




\section{Fundic Relaxants}

Statement 11: Fundic relaxant drugs may be effective in improving generalized dyspeptic symptoms, postprandial fullness, and early satiation.

Grade of recommendation: weak

Level of evidence: moderate

Impaired relaxation of the proximal part of the stomach to accommodate a meal is present in $40.0 \%$ of patients with $\mathrm{FD}$ and is a pathophysiological mechanism that is associated with symptoms such as early satiation and weight loss. ${ }^{120}$ Buspirone and tandospirone are $5-\mathrm{HT}_{1}$ receptor agonists and have fundic relaxation effects. ${ }^{121}$ In a randomized, double-blind, crossover study, buspirone significantly increased gastric accommodation after 4 weeks of treatment. It significantly reduced the overall severity of dyspeptic symptoms and individual symptoms of postprandial fullness, early satiation, and abdominal bloating. ${ }^{122}$ In a double-blind, placebocontrolled study, tandospirone significantly improved total abdominal symptom scores and upper abdominal pain in patients with FD. ${ }^{123} 5-\mathrm{HT}_{4}$ receptor agonists such as cisapride, tegaserod, and mosapride citrate can enhance meal-induced gastric accommodation and improve the symptoms of some patients with FD. ${ }^{74,124}$ ${ }^{126}$ Acotiamide acts as a muscarinic receptor antagonist and cholinesterase antagonist, improves gastric emptying, and enhances fundic relaxation. In an RCT that used real-time ultrasonography, acotiamide significantly enhanced postprandial gastric accommodation reflex in patients with $\mathrm{FD} .{ }^{127}$ A placebo-controlled study that used gastric scintigraphy demonstrated that acotiamide significantly increased gastric accommodation and improved overall GI symptoms and anxiety scores. ${ }^{91}$ Some antidepressants also have fundic relaxant activity and improve gastric accommodation. In a doubleblind, placebo-controlled study, amitriptyline and escitalopram were administered for 12 weeks, and single-photon emission computed tomography imaging was used to measure the gastric accommodation. These drugs significantly improved gastric accommodation; however, further studies of the precise mechanism of action are needed. $^{128}$

\section{Antidepressants}

Statement 12: TCAs may be effective in functional dyspeptic patients who do not respond to conventional therapy.

Grade of recommendation: weak

Level of evidence: moderate 


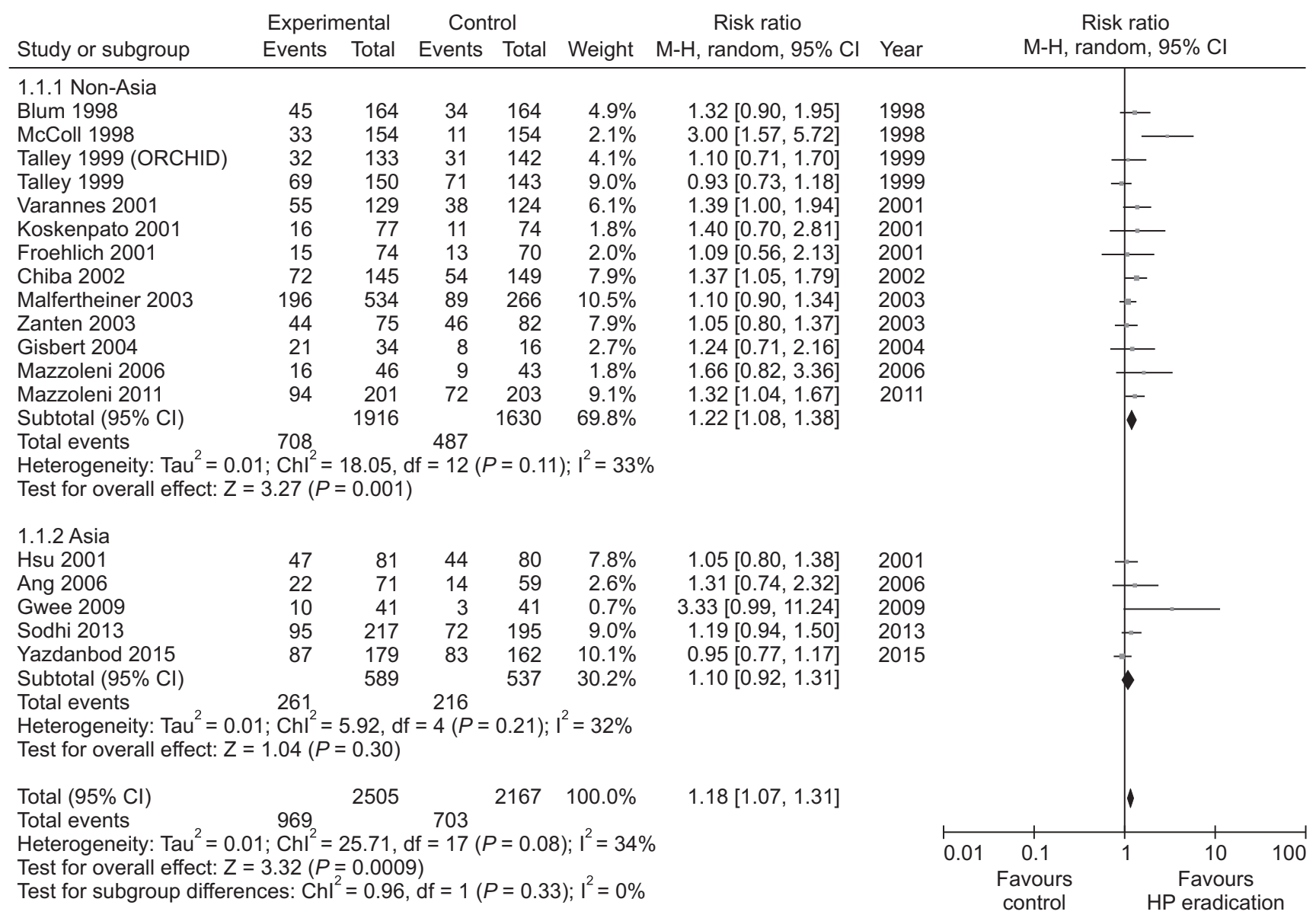

Figure 5. Forest plot of randomized controlled trials comparing Helicobacter pylori eradication with placebo antibiotics in $H$. pylori infected patients with functional dyspepsia. HP, Helicobacter pylori.

Experts' opinions: completely agree, $34.6 \%$; mostly agree, $53.9 \%$; partially agree, $11.5 \%$; mostly disagree, $0.0 \%$; completely disagree, $0.0 \%$; and not sure, $0.0 \%$.

TCAs are used clinically to improve symptoms in patients with functional GI disorders. A recent guideline from Korea recommended that TCAs can be considered for symptom improvement in IBS patients. ${ }^{11}$ Recently, 2 systematic reviews compared TCAs with placebo in patients with FD. ${ }^{129,130}$ The first review included 4 RCTs and found that administration of TCAs was associated with reduced number of patients showing no improvement in symptoms compared with placebo (RR, 0.76; 95\% CI, 0.62-0.94) with an NNT of 7 (95\% CI, 4-26). ${ }^{129}$ The second review included 3 RCTs and found TCAs to be effective in reducing dyspeptic symptoms (RR, 0.74; 95\% CI, 0.61-0.91) with an NNT of 6 (95\% CI, $6-18) .{ }^{130}$ Our systematic review identified one $\mathrm{RCT}^{131}$ that was not included in the previous review. Meta-analysis including this study found TCAs to be effective in symptom improvement compared to placebo (RR, 0.78; 95\% CI, 0.64-0.93; $P=0.008$ ) (Fig. 6 and Supplementary Fig. 6-8). Data pooled from these studies found that the incidence of adverse effects were not higher among those taking TCAs (RR, 1.56; 95\% CI, 0.88-2.76; $P=0.13$ ) (Fig. 7).

Two RCTs from Asia compared TCAs with placebo for patients with refractory FD. ${ }^{131,132}$ The first study found imipramine to be effective in relief of dyspeptic symptoms after 12 weeks of administration, compared with placebo. ${ }^{131}$ However, the other study reported that nortriptyline failed to achieve reduction in dyspeptic symptoms after 8 weeks of treatment. ${ }^{132}$ There was a research showing that TCAs were more effective in treating ulcer-like FD, corresponding to the EPS type, than in dysmotility-like FD. ${ }^{133}$ In summary, TCAs may be effective in treatment of refractory FD, especially for patients with the EPS type. Although there was no statistically significant difference in adverse events between TCAs and placebo in our study, patients should be cautioned about the adverse event profiles. In addition, further studies are needed to evaluate the 
anxiety, depression, and psychological distress than those with no FD as found in a study. ${ }^{140}$ Psychological therapies for patients with FD have included dynamic psychotherapy, hypnotherapy, behavioral treatments, and cognitive-behavioral therapy. ${ }^{141-143}$ A systematic review showed insufficient evidence on the efficacy of psychotherapies in non-ulcer dyspepsia although in one trial, hypnotherapy was significantly superior to the control. ${ }^{141,144}$

A prospective RCT showed that 4 month-intensified medical management (medical therapy with testing-for and targeting-of abnormalities of motor and sensory function) with psychological intervention was significantly beneficial in reducing dyspepsia symptoms that did not respond to conventional therapy. Additional cognitive behavioral therapy may be especially effective for control of concomitant anxiety and depression. ${ }^{145}$ Another RCT of a 10week group psychotherapy in combination with standard medical treatment showed significantly improved dyspeptic symptoms and dyspepsia-related quality of life, compared with medical therapy alone. $^{146}$

A recent systematic review showed a significant benefit of psychological therapies in reducing dyspepsia symptoms (RR, 0.53; 95\% CI, 0.44-0.65) with an NNT of 3 . The review included studies that described the outcome in terms of a dichotomous improvement in dyspepsia symptoms in $789 \mathrm{FD}$ patients. ${ }^{36}$ The outcomes of psychological intervention had negative association with poor sleep quality (OR, 7.68; 95\% CI, 1.83-32.25) and bad marriage status (OR, 1.22; 95\% CI, 1.10-1.36), but positive association with extroversion in personality traits $(\mathrm{OR}, 0.86 ; 95 \% \mathrm{CI}, 0.76-0.96){ }^{147}$ Considering all these, psychological therapies can be considered in severely affected FD patients that are not responding to drug therapies, especially if the symptoms may be related to psychological factors.

\section{Diet}

Statement 14: Dietary modification may be effective for symptom relief in patients with FD.

Grade of recommendation: weak

Level of evidence: low

Although dietary factor is considered to have an important role in patients with $\mathrm{FD}$, studies on the causal relationship of specific foods with FD are still lacking and inconsistent. Generally, it is desirable to avoid foods that induce dyspeptic symptoms. Fatty foods particularly exacerbate or induce dyspeptic symptoms. Intraduodenal lipid increases sensitivity to gastric distension and induces abdominal fullness and discomfort in patients with FD. ${ }^{148}$ There was a trend for a reduction in fat intake in FD patients, and post-prandial fullness and bloating were related directly to high fat intake. ${ }^{149}$ High fat intake was also found to induce nausea and abdominal pain in FD patients more than in healthy controls. ${ }^{150}$ Milk and dairy food, wheat-containing food and spicy food may also provoke dyspeptic symptoms. ${ }^{151,152}$ Carbonated drinks and coffee are associated with dyspeptic symptoms. ${ }^{152,153}$ However, there are no clear evidences of a role for dietary intervention with respect to these specific foods for the purpose of dyspeptic symptom relief, and well-designed studies are needed.

\section{Conclusions}

Dyspepsia is a common clinical problem. GI endoscopy should be performed in patients older than 40 years to rule out organic cause, especially gastric cancer. If the symptoms become chronic or repeat after the elimination of the underlying disease, patients with FD should be treated with PPIs, especially in EPS subtypes. Although $\mathrm{H}_{2}$ RAs were shown to be as effective, their effectiveness is unknown for long-term use. Prokinetics such as dopamine $\mathrm{D}_{2}$ antagonists and $5-\mathrm{HT}_{4}$ receptor agonists could be used for patients with FD, especially in PDS subtypes. Some $\mathrm{D}_{2}$ antagonists need to be used carefully as they can cause adverse reactions during longterm use. Meta-analysis shows significant but modest efficacy of $H$. pylori eradication on long-term resolution of FD symptom. $H$. pylori eradication therapy can be applied in case if PPIs and prokinetics are not effective, or in young patients with chronic dyspeptic symptoms in Korea. TCAs may be effective in treatment of non-responder to conventional management of $\mathrm{FD}$, especially for patients with the EPS type. Since the pathophysiology of FD is diverse, it is necessary to elaborate on drug therapy, stress management, and dietary education in order to avoid the recurrence of symptoms. In addition, detailed guidance and education on the disease will be helpful for proper treatment and long-term management.

\section{Supplementary Materials}

Note: To access the supplementary tables and figures mentioned in this article, visit the online version of Journal of Neurogastroenterology and Motility at http://www.jnmjournal.org/, and at https://doi.org/10.5056/jnm19209.

Acknowledgements: We are grateful to all who participated in this study. We thank Prof. Moo In Park and Prof. Suck Chei Choi for working as external judges. In addition, we also thank Prof. Ein- 
Soon Shin for helping us develop the guidelines.

\section{Financial support: None.}

\section{Conflicts of interest: None.}

Author Contributions: Jung Hwan Oh, Joong Goo Kwon, and Hye-Kyung Jung have contributed in writing and editing the paper as the first author and the corresponding author; Kyung Ho Song, Seung Joo Kang, Sung Eun Kim, Joon Sung Kim, Jong Kyu Park, Ki Bae Bang, Myong Ki Baeg, Jeong Eun Shin, Cheol Min Shin, Ju Yup Lee, Hyun Chul Lim, Kyoungwon Jung, and Chung Hyun Tae have contributed in the systematic review, the extraction of recommendations, and writing the paper; and Hye-Kyung Jung has designed the development of guideline as the chairman of the committee.

\section{References}

1. Tack J, Talley NJ, Camilleri M, et al. Functional gastroduodenal disorders. Gastroenterology 2006;130:1466-1479.

2. Stanghellini V, Chan FK, Hasler WL, et al. Gastroduodenal disorders. Gastroenterology 2016;150:1380-1392.

3. Sugano K, Tack J, Kuipers EJ, et al. Kyoto global consensus report on Helicobacter pylori gastritis. Gut 2015;64:1353-1367.

4. Hooi JKY, Lai WY, Ng WK, et al. Global prevalence of Helicobacter pylori infection: systematic review and meta-analysis. Gastroenterology 2017;153:420-429.

5. Kim BJ, Kim HS, Song HJ, et al. Online registry for nationwide database of current trend of Helicobacter pylori eradication in Korea: interim analysis. J Korean Med Sci 2016;31:1246-1253.

6. Bak YT. [Evidence based guideline for diagnosis and treatment: Therapeutic guideline for GERD.] Kor J Neurogastroenterol Motil 2005;11:13-17. [Korean]

7. Jee SR, Jung HK, Min BH, et al. [Guidelines for the treatment of functional dyspepsia.] Korean J Gastroenterol 2011;57:67-81.[Korean]

8. Higgins JP, Altman DG, Gøtzsche PC, et al. The cochrane collaboration's tool for assessing risk of bias in randomised trials. BMJ 2011;343:d5928.

9. Mühlbacher AC, Sadler A, Kaczynski A. Patients' preferences in functional dyspepsia and motility disorder: a discrete-choice experiment. Value in Health 2016;19:A316.

10. Schünemann H, Brożek J, Guyatt G, Oxman A. GRADE handbook. Available from URL: https://gdt.gradepro.org/app/handbook/handbook.html (accessed 9 December, 2019).

11. Song KH, Jung HK, Kim HJ, et al. Clinical practice guidelines for irritable bowel syndrome in Korea, 2017 revised edition. J Neurogastroenterol Motil 2018;24:197-215.

12. Malfertheiner P, Megraud F, O'Morain CA, et al. Management of Helicobacter pylori infection-the maastricht $\mathrm{v} /$ florence consensus report.
Gut 2017;66:6-30.

13. Gastro-oesophageal reflux disease and dyspepsia in adults: investigation and management. Available from URL: https:/www.nice.org.uk/guidance/cg184. (accessed 9 Desember, 2019)

14. Miwa H, Kusano M, Arisawa T, et al. Evidence-based clinical practice guidelines for functional dyspepsia. J Gastroenterol 2015;50:125-139.

15. Talley NJ, Lam SK, Goh KL, Fock KM. Management guidelines for uninvestigated and functional dyspepsia in the Asia-Pacific region: first Asian Pacific working party on functional dyspepsia. J Gastroenterol Hepatol 1998;13:335-353.

16. Talley NJ, Vakil N. Guidelines for the management of dyspepsia. Am J Gastroenterol 2005;100:2324-2337.

17. Zhao B, Zhao J, Cheng WF, et al. Efficacy of Helicobacter pylori eradication therapy on functional dyspepsia: a meta-analysis of randomized controlled studies with 12-month follow-up. J Clin Gastroenterol 2014;48:241-247.

18. Lassen AT, Hallas J, Schaffalitzky de Muckadell OB. Helicobacter pylori test and eradicate versus prompt endoscopy for management of dyspeptic patients: 6.7 year follow up of a randomised trial. Gut 2004;53:1758-1763.

19. Lassen AT, Pedersen FM, Bytzer P, Schaffalitzky de Muckadell OB. Helicobacter pylori test-and-eradicate versus prompt endoscopy for management of dyspeptic patients: a randomised trial. Lancet 2000;356:455-460.

20. Bytzer P, Hansen JM, Schaffalitzky de Muckadell OB. Empirical $\mathrm{H}_{2-}$ blocker therapy or prompt endoscopy in management of dyspepsia. Lancet 1994;343:811-816.

21. Laheij RJ, Severens JL, Van de Lisdonk EH, Verbeek AL, Jansen JB. Randomized controlled trial of omeprazole or endoscopy in patients with persistent dyspepsia: a cost-effectiveness analysis. Aliment Pharmacol Ther 1998;12:1249-1256.

22. Li XB, Liu WZ, Ge ZZ, Chen XY, Shi Y, Xiao SD. Helicobacter pylori "test-and-treat" strategy is not suitable for the management of patients with uninvestigated dyspepsia in Shanghai. Scand J Gastroenterol 2005;40:1028-1031.

23. Liou JM, Lin JT, Wang HP, et al. The optimal age threshold for screening upper endoscopy for uninvestigated dyspepsia in Taiwan, an area with a higher prevalence of gastric cancer in young adults. Gastrointest Endosc 2005;61:819-825.

24. Shin A, Kim J, Park S. Gastric cancer epidemiology in Korea. J Gastric Cancer 2011;11:135-140.

25. Song M, Kang D, Yang JJ, et al. Age and sex interactions in gastric cancer incidence and mortality trends in Korea. Gastric Cancer 2015;18:580-589.

26. Hwang IR, Kim JH, Lee KJ, Cho SW. Can Helicobacter pylori serology predict non-ulcer dyspepsia in young dyspeptic patients? Korean J Gastrointest Endosc 2000;21:696-703.

27. Talley NJ, Ford AC. Functional dyspepsia. N Engl J Med 2015;373:1853-1863.

28. Suzuki H, Moayyedi P. Helicobacter pylori infection in functional dyspepsia. Nat Rev Gastroenterol Hepatol 2013;10:168-174.

29. Delaney B, Ford AC, Forman D, Moayyedi P, Qume M. Initial 
management strategies for dyspepsia. Cochrane Database Syst Rev 2005;19:CD001961.

30. Harvey RF, Lane JA, Nair P, et al. Clinical trial: prolonged beneficial effect of Helicobacter pylori eradication on dyspepsia consultations - the Bristol Helicobacter Project. Aliment Pharmacol Ther 2010;32:394400.

31. Lee JH, Choi KD, Jung HY, et al. Seroprevalence of Helicobacter pylori in Korea: a multicenter, nationwide study conducted in 2015 and 2016. Helicobacter 2018;23:e12463.

32. Eusebi LH, Zagari RM, Bazzoli F. Epidemiology of Helicobacter pylori infection. Helicobacter 2014;19(suppl 1):1-5.

33. Talley NJ, Vakil NB, Moayyedi P. American gastroenterological association technical review on the evaluation of dyspepsia. Gastroenterology 2005;129:1756-1780.

34. Veldhuyzen van Zanten SJ, Bradette M, Chiba N, et al. Evidence-based recommendations for short- and long-term management of uninvestigated dyspepsia in primary care: an update of the Canadian Dyspepsia Working Group (CanDys) clinical management tool. Can J Gastroenterol 2005;19:285-303.

35. Moayyedi P, Talley NJ, Fennerty MB, Vakil N. Can the clinical history distinguish between organic and functional dyspepsia? JAMA 2006;295:1566-1576.

36. Moayyedi PM, Lacy BE, Andrews CN, Enns RA, Howden CW, Vakil N. ACG and CAG clinical guideline: management of dyspepsia. Am J Gastroenterol 2017;112:988-1013.

37. Jung KW, Won YJ, Kong HJ, Lee ES. Prediction of cancer incidence and mortality in korea, 2018. Cancer Res Treat 2018;50:317-323.

38. Chen SL, Gwee KA, Lee JS, et al. Systematic review with meta-analysis: prompt endoscopy as the initial management strategy for uninvestigated dyspepsia in Asia. Aliment Pharmacol Ther 2015;41:239-252.

39. Miwa H, Ghoshal UC, Fock KM, et al. Asian consensus report on functional dyspepsia. J Gastroenterol Hepatol 2012;27:626-641.

40. Park JS, Park DI, Park SK, et al. Endoscopic evaluation of significant gastrointestinal lesions in patients with iron deficiency with and without anaemia: a Korean association for the study of intestinal disease study. Intern Med J 2009;39:441-446.

41. Qu XH, Huang XL, Xiong P, et al. Does Helicobacter pylori infection play a role in iron deficiency anemia? A meta-analysis. World J Gastroenterol 2010;16:886-896.

42. Goddard AF, James MW, McIntyre AS, Scott BB. Guidelines for the management of iron deficiency anaemia. Gut 2011;60:1309-1316.

43. Malfertheiner P, Megraud F, O'Morain CA, et al. Management of Helicobacter pylori infection--the maastricht IV/ florence consensus report. Gut 2012;61:646-664.

44. Ryu E, Kim K, Cho MS, Kwon IG, Kim HS, Fu MR. Symptom clusters and quality of life in Korean patients with hepatocellular carcinoma. Cancer Nurs 2010;33:3-10.

45. Son HJ, Rhee PL, Kim JJ, Koh KC, Paik SW, Rhee JC. Hypersensitivity to acid in ulcer-like functional dyspepsia. Korean J Intern Med 1997;12:188-192.

46. Samsom M, Verhagen MA, vanBerge Henegouwen GP, Smout AJ. Abnormal clearance of exogenous acid and increased acid sensitiv- ity of the proximal duodenum in dyspeptic patients. Gastroenterology 1999;116:515-520

47. Lee KJ, Tack J. Duodenal implications in the pathophysiology of functional dyspepsia. J Neurogastroenterol Motil 2010;16:251-257.

48. Pinto-Sanchez MI, Yuan Y, Hassan A, Bercik P, Moayyedi P. Proton pump inhibitors for functional dyspepsia. Cochrane Database Syst Rev 2017;11:CD011194.

49. Gerson LB, Triadafilopoulos G. A prospective study of oesophageal 24-h ambulatory $\mathrm{pH}$ monitoring in patients with functional dyspepsia. Dig Liver Dis 2005;37:87-91.

50. van Zanten SV, Armstrong D, Chiba N, et al. Esomeprazole $40 \mathrm{mg}$ once a day in patients with functional dyspepsia: the randomized, placebocontrolled "ENTER" trial. Am J Gastroenterol 2006;101:2096-2106.

51. Talley NJ, Vakil N, Lauritsen K, et al. Randomized-controlled trial of esomeprazole in functional dyspepsia patients with epigastric pain or burning: does a 1-week trial of acid suppression predict symptom response? Aliment Pharmacol Ther 2007;26:673-682.

52. van Rensburg C, Berghöfer P, Enns R, et al. Efficacy and safety of pantoprazole $20 \mathrm{mg}$ once daily treatment in patients with ulcer-like functional dyspepsia. Curr Med Res Opin 2008;24:2009-2018.

53. Fletcher J, Derakhshan MH, Jones GR, Wirz AA, McColl KE. BMI is superior to symptoms in predicting response to proton pump inhibitor: randomised trial in patients with upper gastrointestinal symptoms and normal endoscopy. Gut 2011;60:442-448.

54. Suzuki H, Kusunoki H, Kamiya T, et al. Effect of lansoprazole on the epigastric symptoms of functional dyspepsia (ELF study): a multicentre, prospective, randomized, double-blind, placebo-controlled clinical trial. United European Gastroenterol J 2013;1:445-452.

55. Iwakiri R, Tominaga K, Furuta K, et al. Randomised clinical trial: rabeprazole improves symptoms in patients with functional dyspepsia in Japan. Aliment Pharmacol Ther 2013;38:729-740.

56. Majewski M, Sarosiek I, Cooper CJ, et al. Gastric $\mathrm{pH}$ and therapeutic responses to exsomeprazole in patients with functional dyspepsia: potential clinical implications. Am J Med Sci 2016;352:582-592.

57. Talley NJ, Meineche-Schmidt V, Paré P, et al. Efficacy of omeprazole in functional dyspepsia: double-blind, randomized, placebo-controlled trials (the Bond and Opera studies). Aliment Pharmacol Ther 1998;12:10551065.

58. Miwa H, Ghoshal UC, Gonlachanvit S, et al. Asian consensus report on functional dyspepsia. J Neurogastroenterol Motil 2012;18:150-168.

59. Miwa H, Kusano M, Arisawa T, et al. Evidence-based clinical practice guidelines for functional dyspepsia. J Gastroenterol 2015;50:125-139.

60. Syam AF, Simadibrata M, Makmun D, et al. National consensus on management of dyspepsia and Helicobacter pylori infection. Acta Med Indones 2017;49:279-287.

61. Moayyedi P, Delaney BC, Vakil N, Forman D, Talley NJ. The efficacy of proton pump inhibitors in nonulcer dyspepsia: a systematic review and economic analysis. Gastroenterology 2004;127:1329-1337.

62. Pinto-Sanchez MI, Yuan Y, Hanssan A, Bercik P, Moayyedi P. Proton pump inhibitors for functional dyspepsia. Cochrane Database Syst Rev 2017;3:CD011194.

63. Talley NJ, Goodsall T, Potter M. Functional dyspepsia. Aust Prescr 
2017;40:209-213.

64. Tack J, Bisschops R, Sarnelli G. Pathophysiology and treatment of functional dyspepsia. Gastroenterology 2004;127:1239-1255.

65. Moayyedi P, Soo S, Deeks J, Delaney B, Innes M, Forman D. Pharmacological interventions for non-ulcer dyspepsia. Cochrane Database Syst Rev 2006; 18:CD001960.

66. Miner PB Jr, Allgood LD, Grender JM. Comparison of gastric $\mathrm{pH}$ with omeprazole magnesium $20.6 \mathrm{mg}$ (Prilosec OTC) o.m. famotidine $10 \mathrm{mg}$ (Pepcid AC) b.d. and famotidine $20 \mathrm{mg}$ b.d. over 14 days of treatment. Aliment Pharmacol Ther 2007;25:103-109.

67. McRorie JW, Kirby JA, Miner PB. Histamine2-receptor antagonists: rapid development of tachyphylaxis with repeat dosing. World J Gastrointest Pharmacol Ther 2014;5:57-62.

68. Hojo M, Nagahara A, Asaoka D, et al. A randomized, double-blind, pilot study of the effect of famotidine on acotiamide treatment for functional dyspepsia. Digestion 2017;96:5-12.

69. Park KH, Pai J, Song DG, et al. Ranitidine-induced anaphylaxis: clinical features, cross-reactivity, and skin testing. Clin Exp Allergy 2016;46:631-639.

70. Veldhuyzen van Zanten SJ, Jones MJ, Verlinden M, Talley NJ. Efficacy of cisapride and domperidone in functional (nonulcer) dyspepsia: a meta-analysis. Am J Gastroenterol 2001;96:689-696.

71. Quigley EM. Prokinetics in the management of functional gastrointestinal disorders. J Neurogastroenterol Motil 2015;21:330-336.

72. Huang X, Lv B, Zhang S, Fan YH, Meng LN. Itopride therapy for functional dyspepsia: a meta-analysis. World J Gastroenterol 2012;18:7371-7377.

73. Talley NJ, Tack J, Ptak T, Gupta R, Giguère M. Itopride in functional dyspepsia: results of two phase III multicentre, randomised, doubleblind, placebo-controlled trials. Gut 2008;57:740-746.

74. Kusunoki H, Haruma K, Hata J, et al. Efficacy of mosapride citrate in proximal gastric accommodation and gastrointestinal motility in healthy volunteers: a double-blind placebo-controlled ultrasonographic study. J Gastroenterol 2010;45:1228-1234.

75. Hallerbäck BI, Bommelaer G, Bredberg E, et al. Dose finding study of mosapride in functional dyspepsia: a placebo-controlled, randomized study. Aliment Pharmacol Ther 2002;16:959-967.

76. Cho YK, Choi MG, Kim SH, et al. [The effect of mosapride on quality of life in functional dyspepsia.] Korean J Gastroenterol 2004;43:160167. [Korean]

77. Bang CS, Kim JH, Baik GH, et al. Mosapride treatment for functional dyspepsia: a meta-analysis. J Gastroenterol Hepatol 2015;30:28-42.

78. Hongo M, Harasawa S, Mine T, et al. Large-scale randomized clinical study on functional dyspepsia treatment with mosapride or teprenone: Japan Mosapride Mega-Study (JMMS). J Gastroenterol Hepatol 2012;27:62-68.

79. Kinoshita Y, Hashimoto T, Kawamura A, et al. Effects of famotidine, mosapride and tandospirone for treatment of functional dyspepsia. Aliment Pharmacol Ther 2005;21(suppl 2):37-41.

80. Otaka M, Jin M, Odashima M, et al. New strategy of therapy for functional dyspepsia using famotidine, mosapride and amitriptyline. Aliment Pharmacol Ther 2005;21(suppl 2):42-46.
81. Yoon H, Lee DH, Lee YH, et al. Efficacy and safety of UI05MSP015CT in functional dyspepsia: a randomized, controlled trial. Gut Liver 2018;12:516-522.

82. Hiyama T, Yoshihara M, Matsuo K, et al. Meta-analysis of the effects of prokinetic agents in patients with functional dyspepsia. J Gastroenterol Hepatol 2007;22:304-310.

83. Pittayanon R, Yuan Y, Bollegala NP, et al. Prokinetics for functional dyspepsia: a systematic review and meta-analysis of randomized control trials. Am J Gastroenterol 2019;114:233-243.

84. Yang YJ, Bang CS, Baik GH, et al. Prokinetics for the treatment of functional dyspepsia: Bayesian network meta-analysis. BMC Gastroenterol 2017; 17:83.

85. Jung HK, Lee KJ, Choi MG, et al. Efficacy of DA-9701 (motilitone) in functional dyspepsia compared to pantoprazole: a multicenter, randomized, double-blind, non-inferiority study. J Neurogastroenterol Motil 2016;22:254-263.

86. Parkman HP, Hasler WL, Fisher RS. American gastroenterological association technical review on the diagnosis and treatment of gastroparesis. Gastroenterology 2004;127:1592-1622.

87. Tatsuta M, Iishi H, Nakaizumi A, Okuda S. Effect of treatment with cisapride alone or in combination with domperidone on gastric emptying and gastrointestinal symptoms in dyspeptic patients. Aliment Pharmacol Ther 1992;6:221-228.

88. Aziz I, Palsson OS, Törnblom H, Sperber AD, Whitehead WE, Simrén M. Epidemiology, clinical characteristics, and associations for symptom-based Rome IV functional dyspepsia in adults in the USA, Canada, and the UK: a cross-sectional population-based study. Lancet Gastroenterol Hepatol 2018;3:252-262.

89. Tack J, Janssen P. Acotiamide (Z-338, YM443), a new drug for the treatment of functional dyspepsia. Expert Opin Investig Drugs 2011;20:701-712.

90. Matsueda K, Hongo M, Tack J, Saito Y, Kato H. A placebo-controlled trial of acotiamide for meal-related symptoms of functional dyspepsia. Gut 2012;61:821-828.

91. Nakamura K, Tomita T, Oshima T, et al. A double-blind placebo controlled study of acotiamide hydrochloride for efficacy on gastrointestinal motility of patients with functional dyspepsia. J Gastroenterol 2017;52:602-610.

92. Xiao G, Xie X, Fan J, et al. Efficacy and safety of acotiamide for the treatment of functional dyspepsia: systematic review and meta-analysis. ScientificWorldJournal 2014;2014:541950.

93. Tack J, Pokrotnieks J, Urbonas G, et al. Long-term safety and efficacy functional dyspepsia (postprandial distress syndrome)-results from the European phase 3 open-label safety trial. Neurogastroenterol Motil 2018;30:e13284.

94. Shinozaki S, Osawa H, Sakamoto H, Hayashi Y, Kawarai Lefor A, Yamamoto $\mathrm{H}$. The effect of acotiamide on epigastric pain syndrome and postprandial distress syndrome in patients with functional dyspepsia. $\mathrm{J}$ Med Invest 2016;63:230-235.

95. Arts J, Caenepeel P, Verbeke K, Tack J. Influence of erythromycin on gastric emptying and meal related symptoms in functional dyspepsia with delayed gastric emptying. Gut 2005;54:455-460. 
96. Janssens J, Peeters TL, Vantrappen G, et al. Improvement of gastric emptying in diabetic gastroparesis by erythromycin. Preliminary studies. N Engl J Med 1990;322:1028-1031.

97. Basch E, Prestrud AA, Hesketh PJ, et al. Antiemetics: American Society of Clinical Oncology clinical practice guideline update. J Clin Oncol 2011;29:4189-4198.

98. Domperidone: ventricular arrhythmia and sudden death (continued). Prescrire Int 2012;21:183.

99. Frommeyer G, Fischer C, Ellermann C, et al. Severe proarrhythmic potential of the antiemetic agents ondansetron and domperidone. Cardiovasc Toxicol 2017;17:451-457.

100. Shin HW, Kim MJ, Kim JS, Lee MC, Chung SJ. Levosulpirideinduced movement disorders. Mov Disord 2009;24:2249-2253.

101. Du LJ, Chen BR, Kim JJ, Kim S, Shen JH, Dai N. Helicobacter pylori eradication therapy for functional dyspepsia: systematic review and metaanalysis. World J Gastroenterol 2016;22:3486-3495.

102. McColl K, Murray L, El-Omar E, et al. Symptomatic benefit from eradicating Helicobacter pylori infection in patients with nonulcer dyspepsia. N Engl J Med 1998;339:1869-1874.

103. Blum AL, Talley NJ, O'Morain C, et al. Lack of effect of treating Helicobacter pylori infection in patients with nonulcer dyspepsia. Omeprazole plus clarithromycin and amoxicillin effect one year after Treatment (OCAY) study group. N Engl J Med 1998;339:1875-1881.

104. Talley NJ, Vakil N, Ballard ED 2nd, Fennerty MB. Absence of benefit of eradicating Helicobacter pylori in patients with nonulcer dyspepsia. N Engl J Med 1999;341:1106-1111.

105. Talley NJ, Janssens J, Lauritsen K, Rácz I, Bolling-Sternevald E. Eradication of Helicobacter pylori in functional dyspepsia: randomised double blind placebo controlled trial with 12 months' follow up. The Optimal Regimen Cures Helicobacter Induced Dyspepsia (ORCHID) study group. BMJ 1999;318:833-837.

106. Koskenpato J, Farkkilä M, Sipponen P. Helicobacter pylori eradication and standardized 3-month omeprazole therapy in functional dyspepsia. Am J Gastroenterol 2001;96:2866-2872.

107. Hsu PI, Lai KH, Tseng HH, et al. Eradication of Helicobacter pylori prevents ulcer development in patients with ulcer-like functional dyspepsia. Aliment Pharmacol Ther 2001;15:195-201.

108. Bruley Des Varannes S, Fléjou JF, Colin R, Zaïm M, Meunier A, Bidaut-Mazel C. There are some benefits for eradicating Helicobacter pylori in patients with non-ulcer dyspepsia. Aliment Pharmacol Ther 2001;15:1177-1185.

109. Froehlich F, Gonvers JJ, Wietlisbach V, et al. Helicobacter pylori eradication treatment does not benefit patients with nonulcer dyspepsia. Am J Gastroenterol 2001;96:2329-2336.

110. Chiba N, Van Zanten SJ, Sinclair P, Ferguson RA, Escobedo S, Grace E. Treating Helicobacter pylori infection in primary care patients with uninvestigated dyspepsia: the Canadian adult dyspepsia empiric treatmentHelicobacter pylori positive (CADET-Hp) randomised controlled trial. BMJ 2002;324:1012-1016.

111. Veldhuyzen van Zanten S, Fedorak RN, Lambert J, Cohen L, Vanjaka A. Absence of symptomatic benefit of lansoprazole, clarithromycin, and amoxicillin triple therapy in eradication of Helicobacter pylori positive, functional (nonulcer) dyspepsia. Am J Gastroenterol 2003;98:19631969.

112. Malfertheiner P, J MOssner J, Fischbach W, et al. Helicobacter pylori eradication is beneficial in the treatment of functional dyspepsia. Aliment Pharmacol Ther 2003;18:615-625.

113. Gisbert JP, Cruzado AI, Garcia-Gravalos R, Pajares JM. Lack of benefit of treating Helicobacter pylori infection in patients with functional dyspepsia. Randomized one-year follow-up study. Hepatogastroenterology 2004;51:303-308.

114. Mazzoleni LE, Sander GB, Ott EA, et al. Clinical outcomes of eradication of Helicobacter pylori in nonulcer dyspepsia in a population with a high prevalence of infection: results of a 12-month randomized, double blind, placebo-controlled study. Dig Dis Sci 2006;51:89-98.

115. Ang TL, Fock KM, Teo EK, et al. Helicobacter pylori eradication versus prokinetics in the treatment of functional dyspepsia: a randomized, double-blind study. J Gastroenterol 2006;41:647-653.

116. Gwee KA, Teng L, Wong RK, Ho KY, Sutedja DS, Yeoh KG. The response of Asian patients with functional dyspepsia to eradication of $\mathrm{He}$ licobacter pylori infection. Eur J Gastroenterol Hepatol 2009;21:417424.

117. Mazzoleni LE, Sander GB, Francesconi CF, et al. Helicobacter pylori eradication in functional dyspepsia: HEROES trial. Arch Intern Med 2011;171:1929-1936.

118. Sodhi JS, Javid G, Zargar SA, et al. Prevalence of Helicobacter pylori infection and the effect of its eradication on symptoms of functional dyspepsia in Kashmir, India. J Gastroenterol Hepatol 2013;28:808-813.

119. Yazdanbod A, Salimian S, Habibzadeh S, Hooshyar A, Maleki N, Norouzvand M. Effect of Helicobacter pylori eradication in Iranian patients with functional dyspepsia: a prospective, randomized, placebocontrolled trial. Arch Med Sci 2015;11:964-969.

120. Tack J, Piessevaux H, Coulie B, Caenepeel P, Janssens J. Role of impaired gastric accommodation to a meal in functional dyspepsia. Gastroenterology 1998;115:1346-1352.

121. Van Oudenhove L, Kindt S, Vos R, Coulie B, Tack J. Influence of buspirone on gastric sensorimotor function in man. Aliment Pharmacol Ther 2008;28:1326-1333.

122. Tack J, Janssen P, Masaoka T, Farré R, Van Oudenhove L. Efficacy of buspirone, a fundus-relaxing drug, in patients with functional dyspepsia. Clin Gastroenterol Hepatol 2012;10:1239-1245.

123. Miwa $\mathrm{H}$, Nagahara A, Tominaga K, et al. Efficacy of the $5-\mathrm{HT}_{1 \mathrm{~A}}$ agonist tandospirone citrate in improving symptoms of patients with functional dyspepsia: a randomized controlled trial. Am J Gastroenterol 2009;104:2779-2787.

124. Tack J, Broeckaert D, Coulie B, Janssens J. The influence of cisapride on gastric tone and the perception of gastric distension. Aliment Pharmacol Ther 1998;12:761-766.

125. Tack J, Janssen P, Bisschops R, Vos R, Phillips T, Tougas G. Influence of tegaserod on proximal gastric tone and on the perception of gastric distention in functional dyspepsia. Neurogastroenterol Motil 2011;23:e32-e39.

126. Amano T, Ariga H, Kurematsu A, et al. Effect of 5-hydroxytryptamine receptor 4 agonist mosapride on human gastric accommodation. Neuro- 
gastroenterol Motil 2015;27:1303-1309.

127. Kusunoki H, Haruma K, Manabe N, et al. Therapeutic efficacy of acotiamide in patients with functional dyspepsia based on enhanced postprandial gastric accommodation and emptying: randomized controlled study evaluation by real-time ultrasonography. Neurogastroenterol Motil 2012;24:540-545, e250-e251.

128. Lacy BE, Saito YA, Camilleri M, et al. Effects of antidepressants on gastric function in patients with functional dyspepsia. Am J Gastroenterol 2018;113:216-224.

129. Lu Y, Chen M, Huang Z, Tang C. Antidepressants in the treatment of functional dyspepsia: a systematic review and meta-analysis. PLoS One 2016;11:e0157798.

130. Ford AC, Luthra P, Tack J, Boeckxstaens GE, Moayyedi P, Talley NJ. Efficacy of psychotropic drugs in functional dyspepsia: systematic review and meta-analysis. Gut 2017;66:411-420.

131. Cheong PK, Ford AC, Cheung CKY, et al. Low-dose imipramine for refractory functional dyspepsia: a randomised, double-blind, placebocontrolled trial. Lancet Gastroenterol Hepatol 2018;3:837-844.

132. Kaosombatwattana U, Pongprasobchai S, Limsrivilai J, Maneerattanaporn M, Leelakusolvong S, Tanwandee T. Efficacy and safety of nortriptyline in functional dyspepsia in Asians: a randomized double-blind placebo-controlled trial. J Gastroenterol Hepatol 2018;33:411-417.

133. Talley NJ, Locke GR, Saito YA, et al. Effect of amitriptyline and escitalopram on functional dyspepsia: a multicenter, randomized controlled study. Gastroenterology 2015;149:340-349, e2.

134. Jaafar MH, Safi SZ, Tan MP, Rampal S, Mahadeva S. Efficacy of rebamipide in organic and functional dyspepsia: a systematic review and meta-analysis. Dig Dis Sci 2018;63:1250-1260.

135. Gudjónsson H, Oddsson E, Björnsson S, et al. Efficacy of sucralfate in treatment of non-ulcer dyspepsia. A double-blind placebo-controlled study. Scand J Gastroenterol 1993;28:969-972.

136. Kairaluoma MI, Hentilae R, Alavaikko M, et al. Sucralfate versus placebo in treatment of non-ulcer dyspepsia. Am J Med 1987;83:51-55.

137. Moayyedi P, Soo S, Deeks J, et al. Systematic review: antacids, H2receptor antagonists, prokinetics, bismuth and sucralfate therapy for nonulcer dyspepsia. Aliment Pharmacol Ther 2003;17:1215-1227.

138. Holtmann G, Gschossmann J, Karaus M, et al. Randomised doubleblind comparison of simethicone with cisapride in functional dyspepsia. Aliment Pharmacol Ther 1999;13:1459-1465.

139. Holtmann G, Gschossmann J, Mayr P, Talley NJ. A randomized placebo-controlled trial of simethicone and cisapride for the treatment of patients with functional dyspepsia. Aliment Pharmacol Ther 2002;16:1641-1648.

140. Adibi P, Keshteli AH, Daghaghzadeh H, Roohafza H, Pournaghshband N, Afshar H. Association of anxiety, depression, and psychological distress in people with and without functional dyspepsia. Adv Biomed Res 2016;5:195.

141. Calvert EL, Houghton LA, Cooper P, Morris J, Whorwell PJ. Longterm improvement in functional dyspepsia using hypnotherapy. Gastroenterology 2002;123:1778-1785.

142. Haug TT, Wilhelmsen I, Svebak S, Berstad A, Ursin H. Psychotherapy in functional dyspepsia. J Psychosom Res 1994;38:735-744.
143. Hamilton J, Guthrie E, Creed F, et al. A randomized controlled trial of psychotherapy in patients with chronic functional dyspepsia. Gastroenterology 2000;119:661-669.

144. Soo S, Forman D, Delaney BC, Moayyedi P. A systematic review of psychological therapies for nonulcer dyspepsia. Am J Gastroenterol 2004;99:1817-1822.

145. Haag S, Senf W, Tagay S, et al. Is there a benefit from intensified medical and psychological interventions in patients with functional dyspepsia not responding to conventional therapy? Aliment Pharmacol Ther 2007;25:973-986.

146. Orive M, Barrio I, Orive VM, et al. A randomized controlled trial of a 10 week group psychotherapeutic treatment added to standard medical treatment in patients with functional dyspepsia. J Psychosom Res 2015;78:563-568.

147. Chen Y, Wang C, Wang J, et al. Association of psychological characteristics and functional dyspepsia treatment outcome: a case-control study. Gastroenterol Res Pract 2016;2016:5984273.

148. Barbera R, Feinle C, Read NW. Nutrient-specific modulation of gastric mechanosensitivity in patients with functional dyspepsia. Dig Dis Sci 1995;40:1636-1641.

149. Pilichiewicz AN, Horowitz M, Holtmann GJ, Talley NJ, Feinle-Bisset C. Relationship between symptoms and dietary patterns in patients with functional dyspepsia. Clin Gastroenterol Hepatol 2009;7:317-322.

150. Pilichiewicz AN, Feltrin KL, Horowitz M, et al. Functional dyspepsia is associated with a greater symptomatic response to fat but not carbohydrate, increased fasting and postprandial CCK, and diminished PYY. Am J Gastroenterol 2008;103:2613-2623.

151. Feinle-Bisset C, Azpiroz F. Dietary and lifestyle factors in functional dyspepsia. Nat Rev Gastroenterol Hepatol 2013;10:150-157.

152. Carvalho RV, Lorena SL, Almeida JR, Mesquita MA. Food intolerance, diet composition, and eating patterns in functional dyspepsia patients. Dig Dis Sci 2010;55:60-65.

153. Mullan A, Kavanagh P, O’Mahony P, Joy T, Gleeson F, Gibney MJ. Food and nutrient intakes and eating patterns in functional and organic dyspepsia. Eur J Clin Nutr 1994;48:97-105. 